Article

\title{
Genesis of Early-Middle Jurassic Intrusive Rocks in the Erguna Block (NE China) in Response to the Late-Stage Southward Subduction of the Mongol-Okhotsk Oceanic Plate: Constraints from Geochemistry and Zircon U-Pb Geochronology and Lu-Hf Isotopes
}

\author{
Anqi Mao ${ }^{1}\left(\mathbb{D}\right.$, Deyou Sun ${ }^{1,2, *}$, Jun Gou ${ }^{1,2}$ and Han Zheng ${ }^{3}(\mathbb{D}$ \\ 1 College of Earth Sciences, Jilin University, Changchun 130061, China; anqimao@outlook.com (A.M.); \\ goujun860411@163.com (J.G.) \\ 2 Key Laboratory of Mineral Resources Evaluation in Northeast Asia, Ministry of Natural Resources, \\ Changchun 130061, China \\ 3 School of Geosciences and Info-Physics, Central South University, Changsha 410083, China; \\ hanzheng@csu.edu.cn \\ * Correspondence: sundy@jlu.edu.cn
}

Received: 26 February 2020; Accepted: 17 April 2020; Published: 20 April 2020

\begin{abstract}
The subduction processes and geodynamic scenarios of the late-stage southward subduction of the Mongol-Okhotsk oceanic slab since the Early Jurassic are subjects of great debate. This contribution presents new $\mathrm{U}-\mathrm{Pb}$ zircon dating, trace element geochemistry, Ti-in zircon geothermometry, and Lu-Hf isotopes of zircon, as well as bulk-rock geochemical data for Early-Middle Jurassic intrusive rocks in the Erguna Block, NE China. Approximately 181-198 Ma monzogranites and ca. 162-174 Ma quartz monzonites were identified in the block. The Early Jurassic monzogranites are high-K calc-alkaline I-type granites, which display moderately concave-upward rare earth element (REE) patterns with slightly negative Eu anomalies, and low zircon crystallization temperatures. The Middle Jurassic quartz monzonites have low $\mathrm{Yb}$ and $\mathrm{Y}$ concentrations, high $\mathrm{Sr} / \mathrm{Y}$ ratios, and strong high field strength elements (HFSEs) depletions, that are in excellent agreement with adakitic rocks. They exhibit right-sloping REE patterns with negligible Eu anomalies, and a wide range of zircon crystallization temperatures. The intrusions yield $\varepsilon_{\mathrm{Hf}}(\mathrm{t})$ values between -4.1 to +4.8 and juvenile two-stage model ( $\left.\mathrm{T}_{\mathrm{DM} 2}\right)$ ages varying from 918-1488 Ma. The geochemical and isotopic signatures suggest that the monzogranites were likely derived by the partial melting of K-rich meta-basalts within the lower part of a juvenile crust that had medium-thickness $(\leq 40 \mathrm{~km})$, with the involvement of minor mantle materials. Whereas, the quartz monzonites were possibly produced by partial melting of a thickened continental lower crust $(\geq 50 \mathrm{~km})$. The Mongol-Okhotsk tectonic regime played a dominant role in accounting for their formation. An Andean-type continental arc setting was developed during the Early-Middle Jurassic, with gradual thickening of the continental crust. The significant crustal thickening may reach its ultimate stage at ca. 162-174 Ma, which marks the tectonic transition from compression to extension. The southward subduction beneath the Erguna Block was continuous and stable during the Early Jurassic. Rollback of the subducted slab occurred at ca. $174-177 \mathrm{Ma}$, followed by moderate magmatic activities represented by adakitic rocks.
\end{abstract}

Keywords: zircon U-Pb dating; Lu-Hf isotopes; geochemistry; intrusive rock; Mongol-Okhotsk Ocean; Erguna Block 


\section{Introduction}

The Mongol-Okhotsk orogenic belt stretches across the Russian Transbaikal and Northeastern (NE) Mongolia (Figure 1a). The belt is considered to be the youngest section of the Central Asian Orogenic Belt (CAOB) that was formed through a gigantic accretionary orogeny from the Neoproterozoic-Late Mesozoic [1-4]. The Mongol-Okhotsk orogenic belt is tectonically situated between the Siberian Craton to the northeast and the collages of Mongolia-NE China continental blocks to the southeast since the Late Paleozoic (Figure 1a,b) [1-4], and its geodynamic evolution played a dominant role in controlling the stratigraphy, magmatism, mineralization, as well as topography of the eastern part of the CAOB during the Mesozoic [5-8].

The Erguna Block of NE China is situated immediately to the southeast of the Mongol-Okhotsk orogenic belt (Figure 1a,b), and is characterized by extensive intrusive and volcanic activities during the Early and Late Mesozoic, respectively [7-10], providing an ideal natural laboratory for exploring the Mesozoic tectonic evolution of the belt in Chinese territory. A large number of geochronological and geochemical studies focusing on the Mesozoic igneous rocks have thus been performed in the past decade (references in Tables S2 and S6), and have made great progress in understanding the early-stage (from Late Permian to Triassic $[7,11]$ ) southward subduction of the Mongol-Okhotsk oceanic plate (MOOP). In contrast, the subduction processes and geodynamic scenarios of the late-stage southward subduction of the MOOP since the Early Jurassic remain pending problems.

Although Early Jurassic subduction-related igneous rocks are widespread in the Erguna Block and adjacent areas (Figure 1c) [11-13], the associated subduction processes remain debatable. Some studies suggest the rollback of a subducted slab with supra subduction extensional settings was involved [12]; while others argue that a stable arc-trench system accompanied by continuous subduction under compressional environments was dominant [11,13]. In contrast to the Early Jurassic igneous rocks, the Middle Jurassic igneous rocks are poorly exposed in the Erguna Block and adjacent regions (Figure 1c). Most previous studies suggest that the Middle Jurassic marks the final closure of the Mongol-Okhotsk Ocean (MOO), and the poor exposure of igneous rocks reflects a magmatic quiescent period related to the continent-continent collision $[7,11,14]$. Other studies argue that some Late Jurassic magmatic rocks were generated by subduction-related processes, and thus the Middle Jurassic tectonic setting of the Erguna Block was controlled by the southward subduction of the MOOP [13,15-17]. These controversies result in an incomplete understanding of the late-stage southward subduction of the MOOP, as well as the tectonic settings in relation to the subduction processes.

In this study, we have first identified two Middle Jurassic intrusions in the Erguna Block and found that the rocks have typical adakitic affinity that indicates an environment of thickened continental crust. Early Jurassic high-K calc-alkaline I-type granites were also identified in the Erguna Block. Here, we present new $\mathrm{U}-\mathrm{Pb}$ dating, trace element geochemistry, Ti-in zircon geothermometry, and Lu-Hf isotopes of zircons, as well as bulk-rock geochemical data for these intrusive rocks. These data enable to constrain the petrogenesis of the intrusions and contribute to infer the associated tectonic settings. For the widespread Early Jurassic igneous rocks in the Erguna Block, a large geochemical, isotopic, and geochronological database was compiled using previously published data (Tables S2, S6 and S8). Comparisons of our data with the large dataset enable a more convincing interpretation of the results. The findings could contribute to constrain the Early-Middle Jurassic tectonic settings of the Erguna Block, and give a better understanding of the subduction processes and geodynamic scenarios of the late-stage southward subduction of the MOOP. 


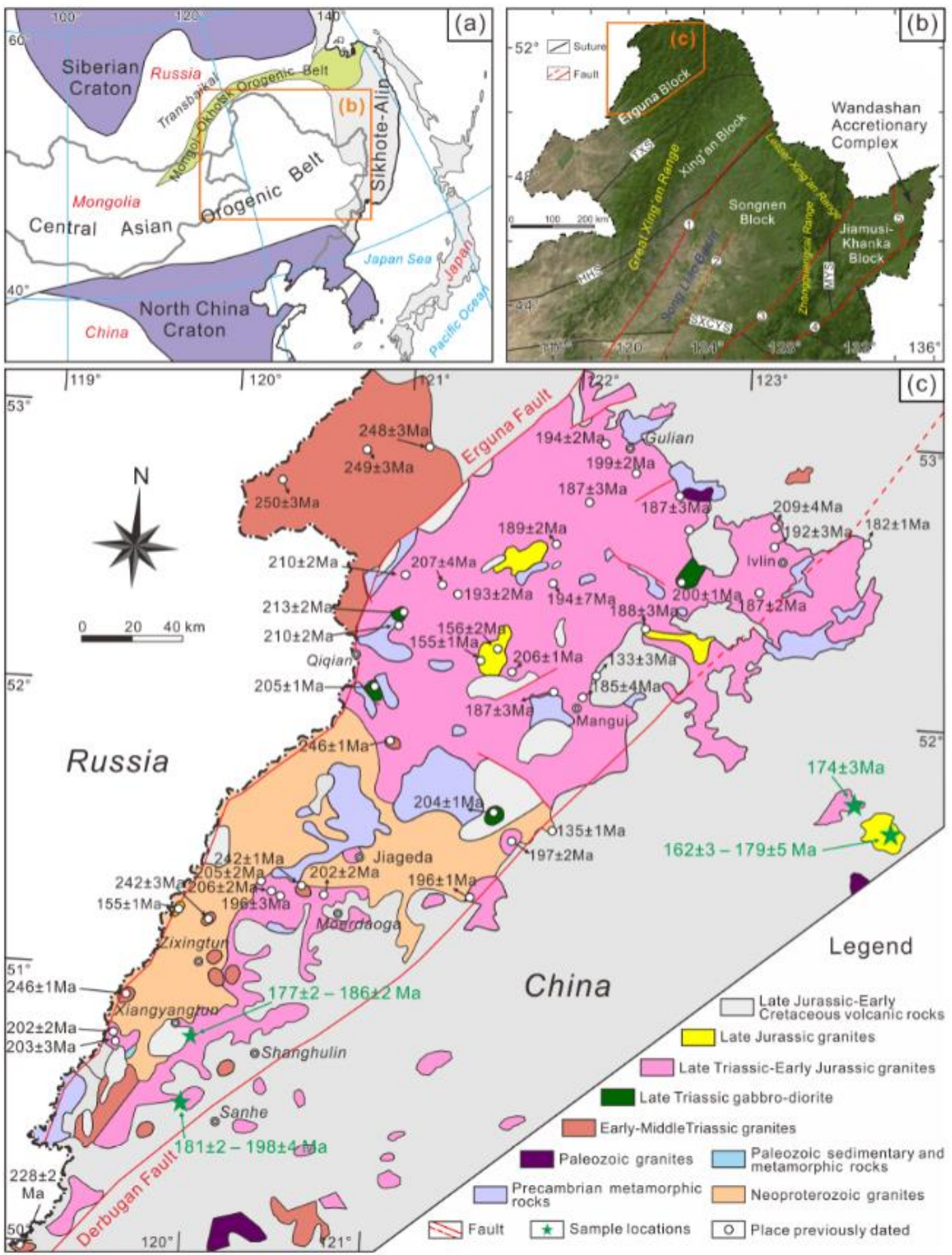

Figure 1. (a) Simplified tectonic map of the Central Asian Orogenic Belt, showing the location of NE China (modified from Safonova and Santosh [18]); (b) Tectonic division of NE China (modified from Wu et al. [9]), abbreviations: TXS-Tayuan-Xiguitu Suture; HHS-Heihe-Hegenshan Suture; MYS-Mudanjiang-Yilan Suture; SXCYS-Solonker-Xar Moron-Changchun-Yanji Suture; 1-Nenjiang-Balihan Fault, 2-Songliao Basin Central Fault, 3-Jiamusi-Yilan Fault, 4-Dunhua-Mishan Fault, 5-Yuejinshan Fault; (c) Simplified geological map of the study area (modified after Wu et al. [9]), showing sampling locations (detailed geographic coordinates are presented in Table S1) and previous zircon $\mathrm{U}-\mathrm{Pb}$ age data from references in Table S2. 


\section{Geological Background and Sample Collections}

NE China is tectonically considered to be the eastern part of the CAOB [19], which lies between the North China Craton in the south and the Siberian Craton in the north (Figure 1a). The NE China region is commonly depicted as a jigsaw of multiple micro-continental blocks, including, from northwest to southeast, the Erguna, Xing'an, Songnen, and Jiamusi-Khanka blocks (Figure 1b) [20,21]. The Paleozoic tectonic evolution of this region was controlled by the amalgamation and collision of these blocks, triggered by the closure of the Paleo-Asian Ocean [1,22]. These blocks docked with the North China Craton in the south during the Late Permian to Middle Triassic by the final closure of the Paleo-Asian Ocean $[1,23]$. Then, the blocks amalgamated with the Siberian Craton in the north during the Late Mesozoic by the closure of the Mongol-Okhotsk Ocean [8-10]. The Mesozoic tectonic history of NE China was constrained by the subduction of the western Pacific Plate and the influence of the Mongol-Okhotsk tectonic regime in the east and west, respectively $[8,9,23,24]$.

The study area is situated in the Erguna Block (Figure 1b). The block is tectonically connected with the central Mongolia blocks [4], and is bound to the northwest and southeast by the Mongol-Okhotsk and Tayuan-Xiguitu suture zones, respectively. The Erguna Block was considered to be amalgamated with the Xing'an Block at ca. 500 Ma [12,25]. The basement of the Erguna Block consists mainly of Precambrian metamorphic supracrustal sequences and intrusive rocks [26]. The metamorphic supracrustal sequences include the Xinghuadukou, Ergunahe, Luomahu, and Jiageda groups, and are mainly composed of gneisses, schists, amphibolites, marbles, leptynites, and migmatites [27]. The intrusive rocks are scattered Paleo-Neoproterozoic granitoids $[7,28]$. The Phanerozoic rocks of the Erguna Block are dominated by Paleozoic marine sequences and widely distributed Mesozoic volcanic successions and terrestrial clastic sediments [8]. Paleozoic and Mesozoic intrusions are extensive in the Erguna Block [9,11]. Emplacement of the magmatic bodies were controlled by the regional structural lineaments, such as the NE-SW-striking Erguna and Derbugan faults [29]. Extensive and intense magmatism occurred mainly during the Mesozoic [11,30], and was intimately related to porphyry $\mathrm{Cu}-\mathrm{Mo}$ deposits during the Late Triassic-Early Jurassic and hydrothermal $\mathrm{Ag}$ and $\mathrm{Pb}-\mathrm{Zn}$ deposits during the Late Jurassic-Early Cretaceous [31-34].

Mesozoic igneous bodies, especially granitoids, are well exposed at the western part of the Erguna Block (Figure 1c). The Late Triassic-Early Jurassic intrusions are the best exposed, followed by Late Jurassic-Early Cretaceous plutons on a much smaller scale [3,6,17]. Conversely, known intrusions of Middle Jurassic age are rare. These magmatic bodies are coexistent with more voluminous volcanic and volcaniclastic rocks (Figure 1c) [7]. In this study, intrusive rock samples were collected from the southern part of a large-scale batholith (samples 14ES14-1 and 14ER546-12), and adjacent isolated granite outcrops (samples 14ER495, 14ER495-1, and 14ER495-2) (Figure 1c). The northern part of the batholith has been studied previously by several works $[4,7,11]$, but the southern part and adjacent intrusive bodies are poorly documented. The samples were preliminarily identified in the field as monzogranitic rocks with variable quartz contents. Other intrusive rock samples were collected from two isolated intrusive bodies (Figure 1c), and were preliminarily identified as quartz monzonitic rocks in the field. All the monzogranitic and quartz monzonitic intrusions are overlain by Late Jurassic-Early Cretaceous volcanic rocks. Sample locations are marked in Figure 1c and presented in Table S1.

\section{Analytical Techniques}

The analytical techniques employed for zircon morphology, trace element compositions, $\mathrm{U}-\mathrm{Pb}$ geochronology, in situ Lu-Hf isotopes, as well as bulk-rock major and trace elements are presented in the Supplementary Materials. 


\section{Results}

\subsection{Petrography}

The monzogranites are reddish-grey in color, medium- to fine-grained, massive, with hypidiomorphic granular texture (Figure 2a). They are composed of quartz (26-32 vol.\%), plagioclase (35-40 vol.\%), K-feldspar (25-30 vol.\%), biotite (4-6 vol.\%), and amphibole (1-2 vol.\%) (Figure 3). Minor apatite, zircon, and sphene occur as accessory phases. The quartz is anhedral-subhedral granular and exhibits a crystal size mainly between $0.05-0.2 \mathrm{~mm}$. The plagioclase commonly occurs as a subhedral platy laths with a crystal size of $0.5-1.5 \mathrm{~mm}$. The K-feldspar is subhedral tabular and anhedral granular with a crystal size mostly ranging from $0.3-1.0 \mathrm{~mm}$. The biotite is tabular in shapes and shows a size between $0.3-0.6 \mathrm{~mm}$ (Figure 2b).
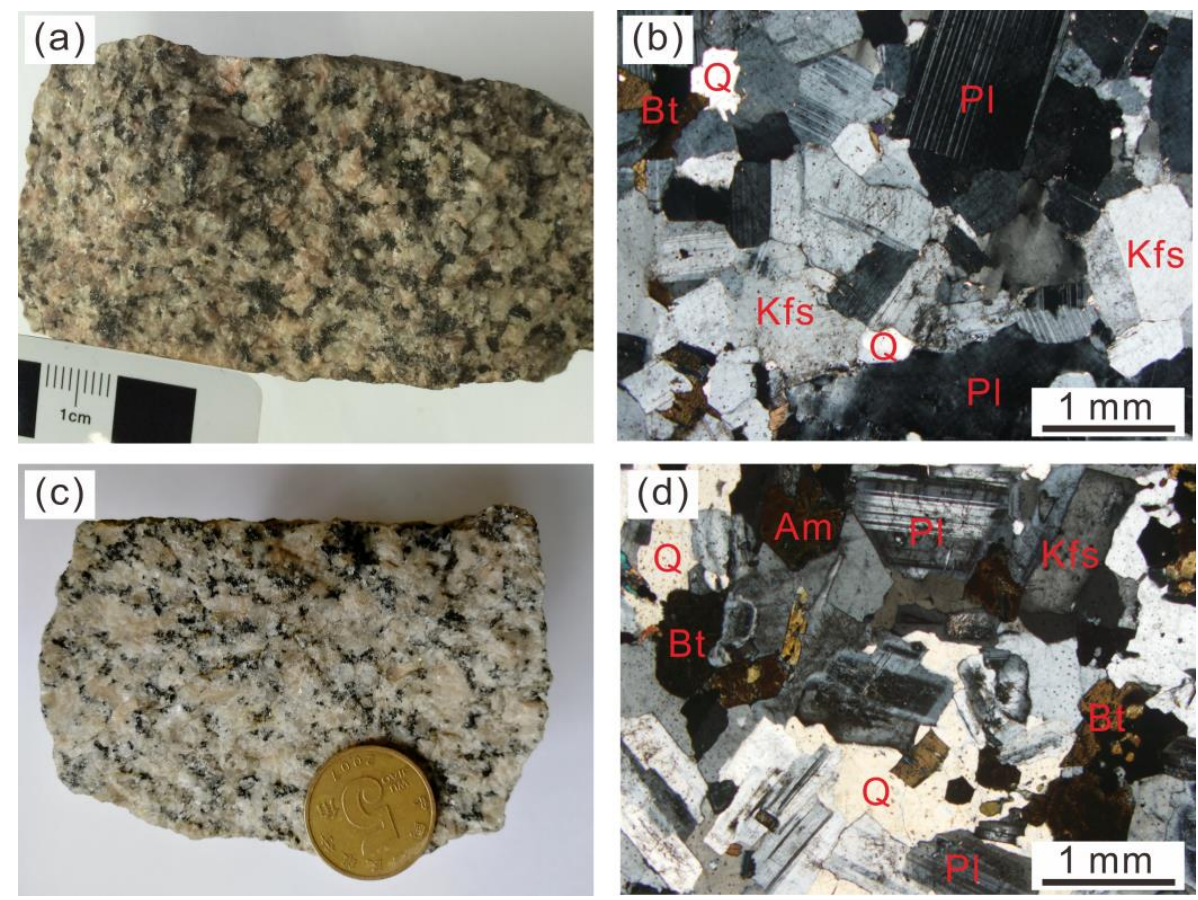

Figure 2. Hand-specimen photographs and microphotographs (crossed polarized light) of representative samples. (a,b) monzogranite (sample 14ER495-1); (c,d) quartz monzonite (sample 18X20-2). Abbreviations: Q—quartz, $\mathrm{Pl}$ —plagioclase, Kfs—K-feldspar, Bt—biotite, Am—amphibole.

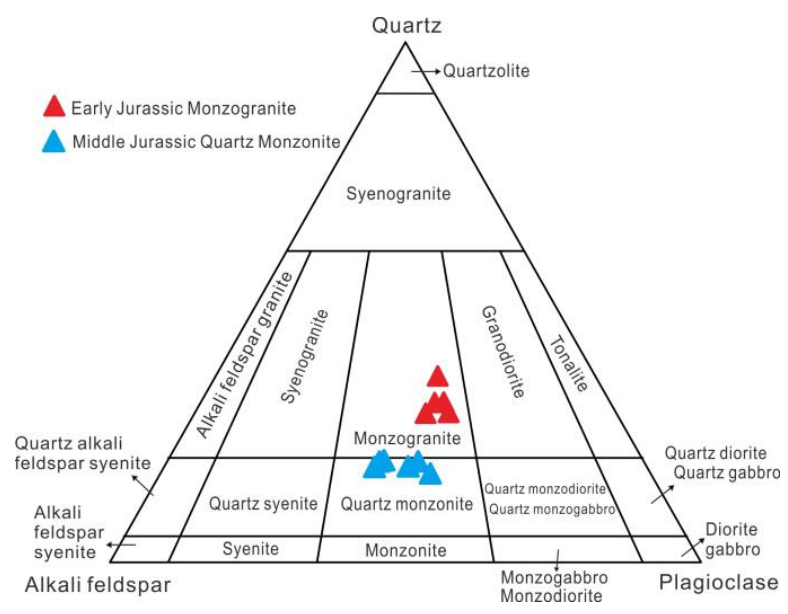

Figure 3. The modal Q-A-P classification of the studied Early-Middle Jurassic intrusive rocks in the Erguna Block (after Streckeisen [35]). 
The quartz monzonites are grey-white in color, fine- to medium-grained, massive, and exhibit a cumulate texture with early crystallizing plagioclases and amphiboles forming a matrix of interlocking euhedral quartz grains (Figure 2c,d). They consist of quartz (15-20 vol.\%), plagioclase (30-40 vol.\%), K-feldspar (35-40 vol.\%), biotite (3-5 vol.\%), amphibole (5-8 vol.\%), as well as accessories of apatite and zircon (Figure 3). The quartz dominantly occurs as irregular and anhedral grains and shows variable grain sizes between $0.1-1.5 \mathrm{~mm}$. The plagioclase forms subhedral laths with $0.4-0.8 \mathrm{~mm}$ in size. The K-feldspar commonly presents as $0.3-0.7-\mathrm{mm}$-sized anhedral-subhedral crystals. The biotite is subhedral and $0.2-0.5-\mathrm{mm}$-sized. The amphibole mostly forms subhedral crystals with $0.3-0.6 \mathrm{~mm}$ in length (Figure 2d).

\subsection{Zircon Morphology, Trace Element Compositions, and $U-P b$ Geochronology}

After detailed petrographic observations, two monzogranite (14ES14 and 14ER495) and two quartz monzonite (18X19 and 18X20) samples from the Erguna Block were chosen for LA-ICP-MS zircon $\mathrm{U}-\mathrm{Pb}$ dating and trace element analyses. The results are given in Tables S3 and S4, respectively. Representative CL images of zircon crystals and U-Pb concordia diagrams are illustrated in Figures 4 and 5 , respectively.

Zircons of the monzogranites vary from $60-200 \mu \mathrm{m}$ in size with aspect ratios of 3:2-3:1. In CL images (Figure 4), these zircons commonly exhibit short prismatic and euhedral morphologies with oscillatory zoning. Zircons of the quartz monzonites have sizes ranging from $60-180 \mu \mathrm{m}$, aspect ratios of 2:1-4:1, euhedral prisms, and oscillatory zoning (Figure 4).
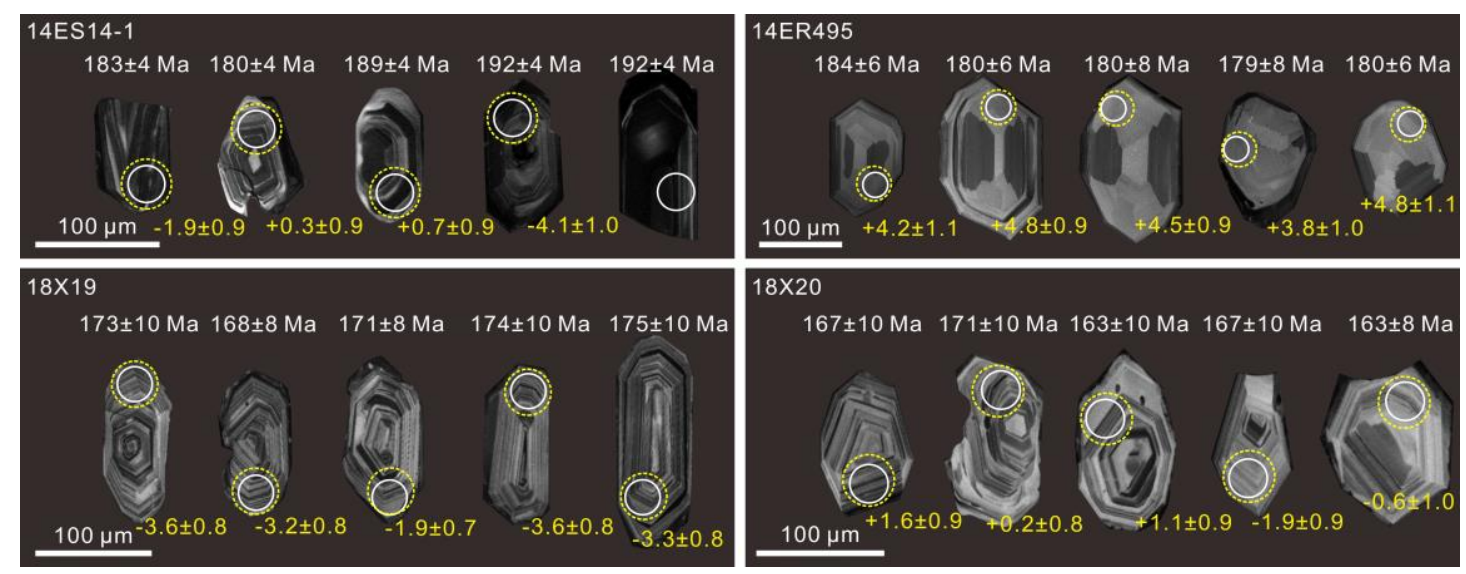

Figure 4. Cathodoluminescence (CL) images of representative zircons from the Early-Middle Jurassic monzogranites and quartz monzonites from the Erguna Block. White solid and yellow dotted circles indicate $\mathrm{U}-\mathrm{Pb}$ and $\mathrm{Lu}-\mathrm{Hf}$ analytical spots, respectively. White and yellow numbers represent ${ }^{206} \mathrm{~Pb} /{ }^{238} \mathrm{U}$ ages and $\varepsilon_{\mathrm{Hf}}(\mathrm{t})$ values (2s uncertainty level) yielded by the zircons, respectively.

Compositionally, zircons from monzogranites exhibit variations of $\mathrm{Ti}$ (6.5-24.7 ppm), Th (31-1142 ppm), U (50-933 ppm), and total REE ( 2 REE) (293-1859 ppm) contents, with Th/U ratios of $0.48-1.72$. Most zircons have positive $\mathrm{Ce}$ anomalies $\left(\mathrm{Ce} / \mathrm{Ce}^{*}=4-435\right)$ and slight Eu anomalies $\left(\mathrm{Eu} / \mathrm{Eu}^{*}=0.10-0.48\right)$ (Figure 5a). Zircons of quartz monzonites contain Ti (2.0-16.5 ppm), Th (101-1056 ppm), U (166-1142 ppm), and $\Sigma$ REE (412-1309 ppm), and have Th/U ratios between 0.56-1.00. Most zircons display positive Ce anomalies $\left(\mathrm{Ce} / \mathrm{Ce}^{*}=5-1343\right)$ and negligible Eu anomalies $\left(\mathrm{Eu} / \mathrm{Eu}^{*}=0.41-0.79\right)$ (Figure 5b), with minor zircons show hydrothermally influenced REE patterns [36]. On La versus $(\mathrm{La} / \mathrm{Yb})_{\mathrm{N}}$ and $(\mathrm{Sm} / \mathrm{La})_{\mathrm{N}}$ versus Ce/Ce $\mathrm{C}^{*}$ diagrams (Figure $\left.5 \mathrm{c}, \mathrm{d}\right)$ [36], the analyzed zircons display a linear trend ranging from magmatic fields toward hydrothermal fields. These features may imply that the zircons have undergone moderate primary high-T hydrothermal alteration during the deuteric stage of magma evolution, with a relatively deep intrusion depth. 

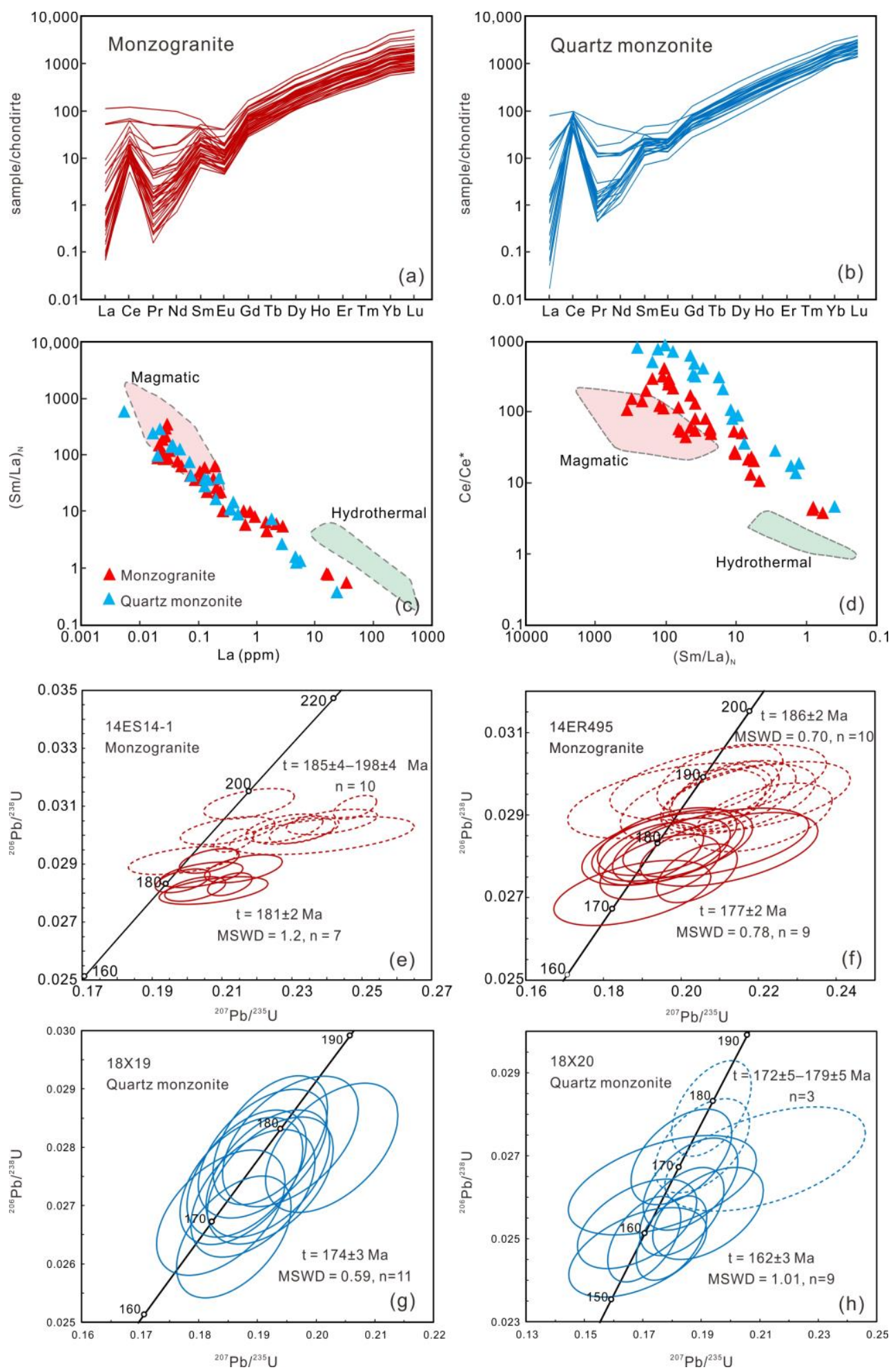

Figure 5. Chondrite-normalized REE variation diagrams of zircons for the (a) Early Jurassic monzogranites and (b) Middle Jurassic quartz monzonites from the Erguna Block; Plots of (c) La versus chondrite-normalized $(\mathrm{La} / \mathrm{Yb})_{\mathrm{N}}$ and $(\mathbf{d})(\mathrm{Sm} / \mathrm{La})_{\mathrm{N}}$ versus Ce/Ce ${ }^{*}$; Zircon U-Pb concordia diagrams for the $(\mathbf{e}, \mathbf{f})$ Early Jurassic monzogranites and $(\mathbf{g}, \mathbf{h})$ Middle Jurassic quartz monzonites (the magmatic and hydrothermal fields in $b$ and $c$ are from Hoskin [36]; chondrite values are from Sun and McDonough [37]). The abbreviation " $\mathrm{t}$ " in $\mathrm{e}-\mathrm{h}$ represents ${ }^{206} \mathrm{~Pb} /{ }^{238} \mathrm{U}$ ages yielded from zircons. 
Only age data with concordance $>87 \%$ have been considered in the following. For monzogranite sample 14ES14-1, three analyses with low concordance $(81.2 \%, 58.5 \%$, and $81.1 \%$ ) were excluded, seven analyses of zircons yielded a weighted mean ${ }^{206} \mathrm{~Pb} /{ }^{238} \mathrm{U}$ age of $181 \pm 2 \mathrm{Ma}$ (MSWD $=1.2$, solid circles in Figure 5e), with the remaining 10 zircons yielding ages ranging from $185 \pm 4$ to $198 \pm 4 \mathrm{Ma}$ (dotted circles in Figure 5e). Among the 20 analyses from monzogranite sample 14ER495, one spot with low concordance $(79.5 \%)$ was excluded, the remaining zircons recorded two resolvable growth events. Nine analyses yielded a weighted mean ${ }^{206} \mathrm{~Pb} /{ }^{238} \mathrm{U}$ age of $177 \pm 2 \mathrm{Ma}(\mathrm{MSWD}=0.78$, solid circles in Figure 5f), with a further nine zircons yielding a weighted mean ${ }^{206} \mathrm{~Pb} /{ }^{238} \mathrm{U}$ age of $186 \pm 2 \mathrm{Ma}$ (MSWD $=0.70$, dotted circles in Figure 5f). The concordia age of ca. $186 \mathrm{Ma}$ (sample 14ER495), and the age range of ca. 185-198 Ma (sample 14ER495) possibly imply the pulse of plutonic activities during the Early Jurassic. The concordia ages of ca. $181 \mathrm{Ma}$ (sample 14ES14-1) and $177 \mathrm{Ma}$ (sample 14ER495) are within error of each other and probably represent the timing of final crystallization of the monzogranite intrusions in the study area.

A total of 11 analyses of zircons from quartz monzonite sample 18X19 yielded a weighted mean ${ }^{206} \mathrm{~Pb} /{ }^{238} \mathrm{U}$ age of $174 \pm 3 \mathrm{Ma}(\mathrm{MSWD}=0.59$, Figure $5 \mathrm{~g}$ ), with one rejected spot (zircon was penetrated during ablation). For quartz monzonite sample $18 \mathrm{X} 20$, nine zircons yielded a weighted mean ${ }^{206} \mathrm{~Pb} /{ }^{238} \mathrm{U}$ age of $162 \pm 3 \mathrm{Ma}$ (MSWD $=1.01$, solid circles in Figure $5 \mathrm{~h}$ ), with a further three zircons yielding ${ }^{206} \mathrm{~Pb} /{ }^{238} \mathrm{U}$ age from $172 \pm 5$ to $179 \pm 5 \mathrm{Ma}$ (dotted circles in Figure $5 \mathrm{~h}$ ). The weighted mean ${ }^{206} \mathrm{~Pb} /{ }^{238} \mathrm{U}$ age of ca. $174 \mathrm{Ma}$ (sample 18X19) is indicative of a Middle Jurassic plutonic activity in the study area, and the age of $162 \pm 3$ Ma obtained from sample 18X20 suggests the final intrusion of the quartz monzonite. The dating results indicate that the quartz monzonites were emplaced during the Middle Jurassic, rather than the Late Triassic-Early Jurassic or Late Jurassic as previously considered by geological mapping [26].

\subsection{Ti-in Zircon Geothermometry and Zircon Saturation Temperature}

The zircon crystallization temperatures of the monzogranites and quartz monzonites were calculated employing the equation for the Ti-in zircon geothermometer established by Ferry and Watson [38] from high-temperature experimental analyses. The Ti concentration in zircon is sensitive to temperature change and could be employed as geothermometer following:

$$
T(\mathrm{~K})=-4800 \pm 86 /\left[\left(\log \mathrm{Ti}(\mathrm{ppm})+\log \alpha \mathrm{SiO}_{2}-\log \alpha \mathrm{TiO}_{2}-(5.711 \pm 0.072)\right]\right.
$$

where $\alpha \mathrm{SiO}_{2}$ and $\alpha \mathrm{TiO}_{2}$ are activity coefficients of $\mathrm{SiO}_{2}$ and $\mathrm{TiO}_{2}$, respectively. For the analyzed monzogranites and quartz monzonites, $\alpha \mathrm{SiO}_{2}$ is assumed to be 1 since $\mathrm{SiO}_{2}$ content has reached saturation evidenced by the existence of quartz, and $\alpha \mathrm{TiO}_{2}$ is assumed to be 0.6 based on the absence of Ti-bearing minerals (e.g., ilmenite and rutile) under optical observations. The calculation results are presented in Table S4. Zircons with Ti concentrations $>100 \mathrm{ppm}$ were rejected during the calculation. For monzogranite sample 14ES14-1, the zircons with ages of ca. $181 \mathrm{Ma}(\mathrm{n}=7)$ yielded crystallization temperatures between $755-803{ }^{\circ} \mathrm{C}$, the zircons with ages between ca. $185-198 \mathrm{Ma}(\mathrm{n}=10)$ yielded temperatures varying from $755-880^{\circ} \mathrm{C}$. For monzogranite sample 14ER495, excluding two zircon with anomalous Ti contents (>100 ppm), zircons with ages of ca. $177 \mathrm{Ma}(\mathrm{n}=9)$ and ca. $186 \mathrm{Ma}(\mathrm{n}=10)$ have crystallization temperatures between $802-900{ }^{\circ} \mathrm{C}$ and $800-834{ }^{\circ} \mathrm{C}$, respectively. Zircons with ages of ca. 177-181 Ma from two samples gave different crystallization temperatures. For quartz monzonite sample $18 X 19,12$ zircons have crystallization temperatures between $652-730^{\circ} \mathrm{C}$. For monzogranite sample 18X20, four zircons with Ti anomalies ( $>100 \mathrm{ppm}$ ) were rejected, the zircons with age of ca. 162 $\mathrm{Ma}(\mathrm{n}=5)$ and $172-179 \mathrm{Ma}(\mathrm{n}=3)$ exhibit crystallization temperatures varying from $772-852{ }^{\circ} \mathrm{C}$ and $772-846^{\circ} \mathrm{C}$, respectively, higher than those of sample $18 \times 19$.

High-temperature experiments $\left(700-1300^{\circ} \mathrm{C}\right)$ suggested that the distribution coefficient of $\mathrm{Zr}$ $\left(D_{\mathrm{Zr}}{ }^{\text {zircon/melt }}\right)$ is a function of the zircon crystallization temperature and corresponding composition 
of the host silicic melt $[39,40]$. The zircon saturation temperature $\left(T_{\mathrm{Zr}}\right)$ can be measured using the following equation:

$$
T_{\mathrm{Zr}}=\left\{12,900 /\left[\ln D_{\mathrm{Zr}} \text { Zircon/Melt }+0.85 \times M+2.95\right]\right\}-273.15
$$

where $D_{\mathrm{Zr}}$ Zircon/Melt is the ratio of $\mathrm{Zr}$ content in zircon to that in the melt, and $M$ is defined as $(2 \mathrm{Ca}+\mathrm{K}+\mathrm{Na}) /(\mathrm{Si} \times \mathrm{Al})_{\text {cation }}$ and obtained using host-rock-normalized concentration. The activity coefficient is presumed to be 1 and $\mathrm{Zr}$ in zircon is considered to be $496000 \times 10^{-6}$ for pure zircons. As shown in Table S5, the obtained $T_{Z r}$ values exhibit a tight range. For the monzogranites and quartz monzonites, $T_{Z \mathrm{rr}}$ values vary between $771-790{ }^{\circ} \mathrm{C}$ and $782-806^{\circ} \mathrm{C}$, respectively.

The zircon crystallization temperatures calculated from the Ti-in zircon geothermometer exhibit a wide range from $755-900{ }^{\circ} \mathrm{C}$ and $652-852^{\circ} \mathrm{C}$ for the monzogranites and quartz monzonites, respectively. These temperatures represent the crystallization of single zircon crystals in the host silicic melt, and generally vary around the corresponding $T_{\mathrm{Zr}}$ values calculated from whole-rocks (Figure S1). Besides, quartz monzonite sample $18 X 19$ has zircon crystallization temperatures much lower than its $T_{Z r}$, suggesting that zircons did not crystalize immediately when $\mathrm{Zr}$ was saturated in the host melt, and the melt probably experienced a complex ascending process.

\subsection{Whole-Rock Major and Trace Elements}

Major and trace element compositions of the monzogranites and quartz monzonites are given in Table S5. All samples have low loss on ignition (LOI) values below $2 \%$, suggesting that the weathering or fluid modification after crystallization can be neglected.

The Early Jurassic monzogranites are plotted on granodiorite and granite fields on a total alkali versus silica (TAS) variation diagram (Figure 6a). They have contents of $\mathrm{SiO}_{2}$ ranging from 65.34-72.80 $\mathrm{wt} \%, \mathrm{Al}_{2} \mathrm{O}_{3}$ of $13.84-15.36 \mathrm{wt} \%, \mathrm{MgO}$ of $0.76-2.13 \mathrm{wt} \%, \mathrm{TiO}_{2}$ of $0.30-0.58 \mathrm{wt} \%, \mathrm{CaO}$ of $1.92-3.88 \mathrm{wt} \%$, $\left(\mathrm{Na}_{2} \mathrm{O}+\mathrm{K}_{2} \mathrm{O}\right)$ of $6.68-7.13 \mathrm{wt} \%$, and $\mathrm{Mg} \#$ values between $49-56$. They are classified as subalkaline series on a TAS diagram (Figure 6a), and as high- $\mathrm{K}$ calc-alkaline rocks on a $\mathrm{K}_{2} \mathrm{O}$ versus $\mathrm{SiO}_{2}$ variation diagram (Figure $6 \mathrm{~b})$. The rocks have $\mathrm{A} / \mathrm{CNK}\left(\right.$ molar $\mathrm{Al}_{2} \mathrm{O}_{3} /\left(\mathrm{CaO}+\mathrm{K}_{2} \mathrm{O}+\mathrm{Na}_{2} \mathrm{O}\right)$ ) values of 0.93-1.05, suggesting that they are metaluminous to slightly peraluminous as supported when plotted on an $\mathrm{A} / \mathrm{NK}$ versus $\mathrm{A} / \mathrm{CNK}$ diagram (Figure $6 \mathrm{c}$ ).
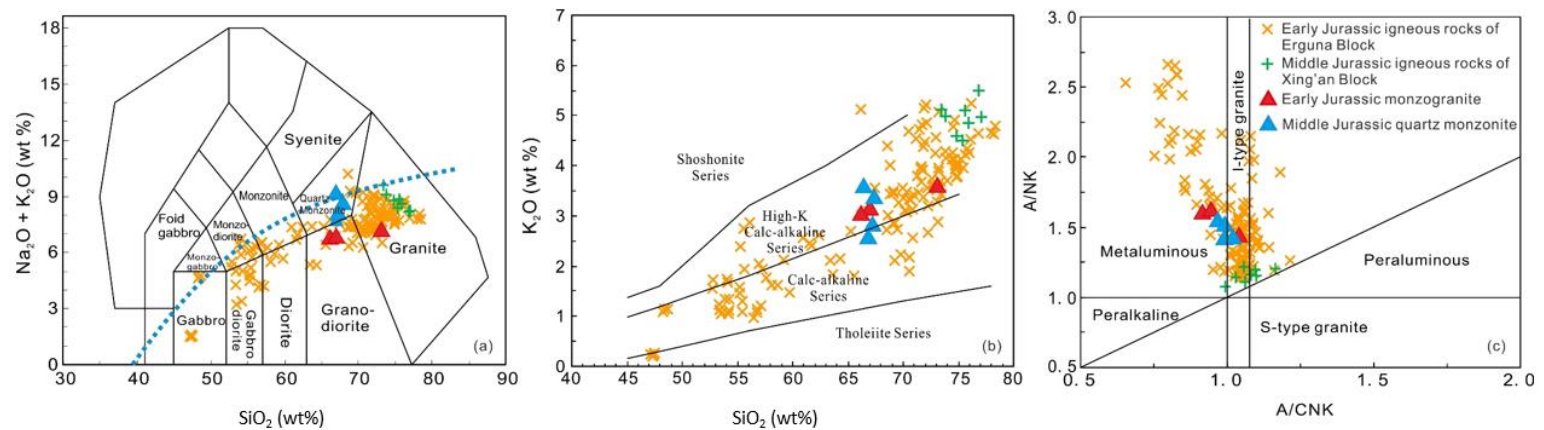

Figure 6. Discrimination diagrams for the Early-Middle Jurassic monzogranites and quartz monzonites from the Erguna Block. (a) $\mathrm{SiO}_{2}$ versus $\left(\mathrm{Na}_{2} \mathrm{O}+\mathrm{K}_{2} \mathrm{O}\right.$ ) (after Irvine and Baragar [41]); (b) $\mathrm{SiO}_{2}$ versus $\mathrm{K}_{2} \mathrm{O}$ (after Peccerillo and Taylor [42]); (c) A/CNK versus A/NK (after Maniar and Piccoli [43]). The solid triangles indicate the data in this study and the + and $\times$ symbols indicate published data (same as below) from references in Table S6.

The monzogranites contain $\Sigma$ REE concentrations ranging from 103.77-141.69 ppm with a mean value of $119.54 \mathrm{ppm}$. They are relatively LREE-enriched $($ LREE $=91.73-133.05 \mathrm{ppm})$ and HREE-depleted (HREE $=8.64-12.04 \mathrm{ppm}$ ), with LREE/HREE $=7.62-15.40$, and chondrite-normalized $(\mathrm{La} / \mathrm{Yb})_{\mathrm{N}}=6.84-20.19$. The samples have moderate negative Eu anomalies $\left(\mathrm{Eu} / \mathrm{Eu}^{*}=0.22-0.82\right.$; with an 
average value of 0.74) and relatively flat HREE trends (Figure 7a). In primitive mantle-normalized trace element spidergrams, the samples exhibit enrichment of LREE and large ion lithophile elements (LILEs; e.g., Rb, Ba, and K), and depletion of HFSEs (e.g., Nb, Ta, and Ti) and P (Figure 7b). They are non-adakitic rocks as their geochemical signatures are distinct from typical adakites derived from both subducted oceanic plate and thickened or delaminated lower crust [44-46]. This is further supported by plots of $(\mathrm{La} / \mathrm{Yb})_{\mathrm{N}}$ versus $\mathrm{Yb}_{\mathrm{N}}$, and $\mathrm{Sr} / \mathrm{Y}$ versus $\mathrm{Y}$ (Figure $8 \mathrm{a}, \mathrm{b}$ ).
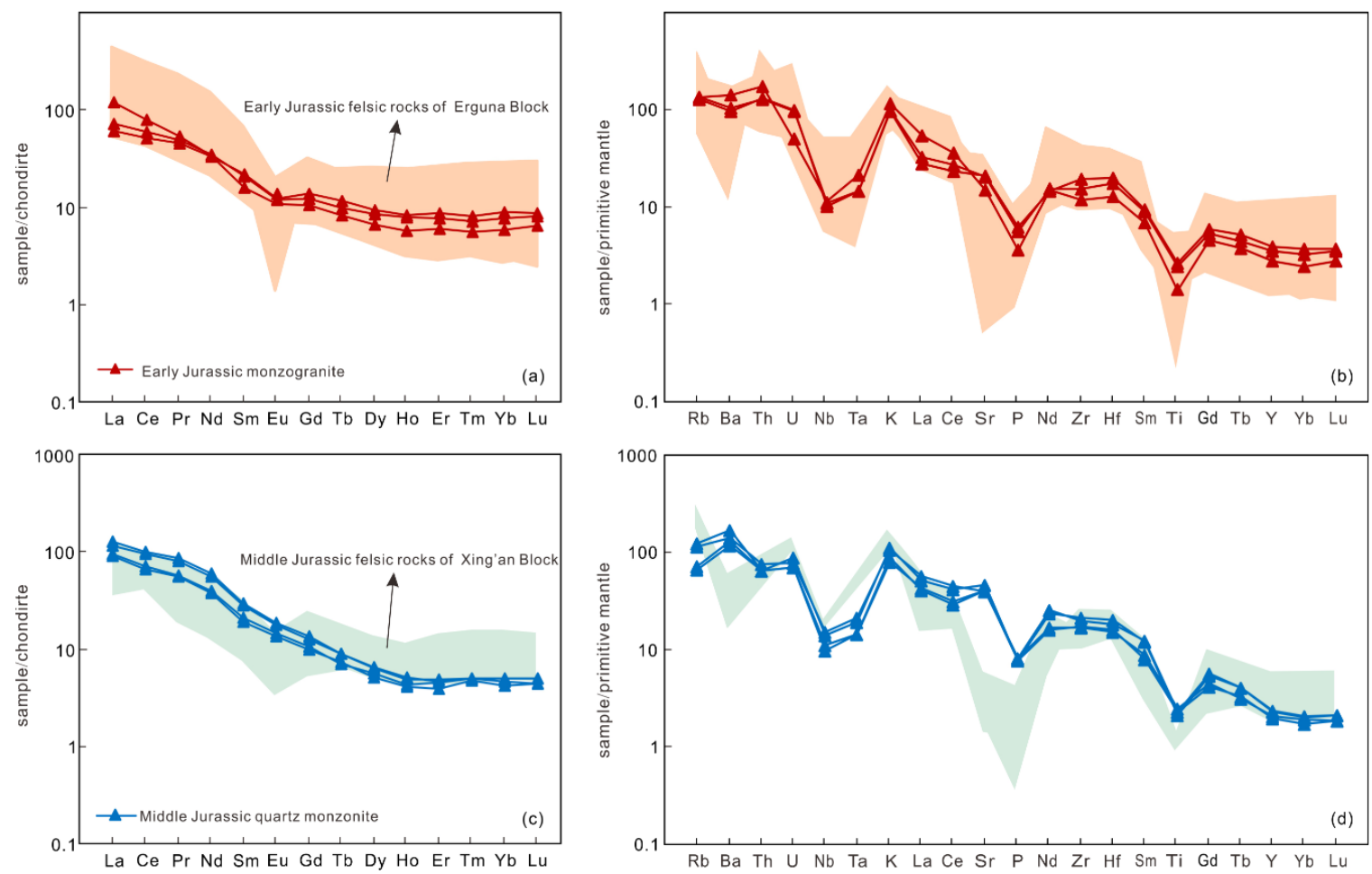

Figure 7. REE patterns $(\mathbf{a}, \mathbf{c})$ and trace element variation diagrams $(\mathbf{b}, \mathbf{d})$ for the Early-Middle Jurassic monzogranites and quartz monzonites from the Erguna Block normalized to chondrite and primitive mantle values from Boynton [47] and Sun and McDonough [37], respectively. The shaded fields represent published data from references in Table S6.

The chemical compositions of Middle Jurassic quartz monzonites are relatively homogenous. They contain 65.38-65.97 wt\% $\mathrm{SiO}_{2}, 16.50-17.53 \mathrm{wt} \% \mathrm{Al}_{2} \mathrm{O}_{3}, 0.47-0.54 \mathrm{wt} \% \mathrm{TiO}_{2}, 2.55-3.38 \mathrm{wt} \% \mathrm{CaO}$, and 7.60-8.97 wt\% $\left(\mathrm{Na}_{2} \mathrm{O}+\mathrm{K}_{2} \mathrm{O}\right)$, with 36-44 Mg\# values. Geochemically, the quartz monzonite samples are considered mainly as subalkaline series in the TAS diagram (Figure 6a) and high-K calc-alkaline rocks on a $\mathrm{K}_{2} \mathrm{O}$ versus $\mathrm{SiO}_{2}$ variation diagram (Figure 6b). The rocks are metaluminous to slightly peraluminous, with A/CNK ratios of 0.97-1.02 (Figure 6c).

The samples have $\Sigma$ REE concentrations of 121.00-181.44 ppm (with an average value of $150.21 \mathrm{ppm}$ ). The REE patterns have strong enrichment in LREE (LREE = 114.16-172.72 ppm; HREE = 6.84-8.72 ppm; $\left.\mathrm{LREE} / \mathrm{HREE}=16.42-19.81 ;(\mathrm{La} / \mathrm{Yb})_{\mathrm{N}}=20.52-25.45\right)$ with uniform, negatively sloped trends, and show negligible $\mathrm{Eu}$ anomalies $\left(\mathrm{Eu} / \mathrm{Eu}^{*}=0.29-0.32\right.$; with a mean value of 0.30) (Figure 7c). On trace element spidergrams (Figure 7d), all samples show sub-parallel trends, with enrichment in the LILEs, such as $\mathrm{Rb}, \mathrm{Ba}, \mathrm{K}$, and depletion in the HFSEs, such as $\mathrm{Nb}$, Ta, and Ti, as well as P. In addition, their negligible Eu anomalies, high Sr contents (847-1000 ppm; with a mean value of 901 ppm), and low Y (9.0-10.9 ppm; with a mean value of $10.0 \mathrm{ppm})$ and $\mathrm{Yb}$ concentrations (0.86-1.03 ppm; with a mean value of $0.97 \mathrm{ppm}$ ) with high $\mathrm{Sr} / \mathrm{Y}$ ratios of 77.7-97.1 (mean value $=0.5$ ) indicate an adakitic affinity, as evidenced when plotted on both the $(\mathrm{La} / \mathrm{Yb})_{\mathrm{N}}$ versus $\mathrm{Yb}_{\mathrm{N}}$, and $\mathrm{Sr} / \mathrm{Y}$ versus $\mathrm{Y}$ diagrams (Figure 8a,b). 

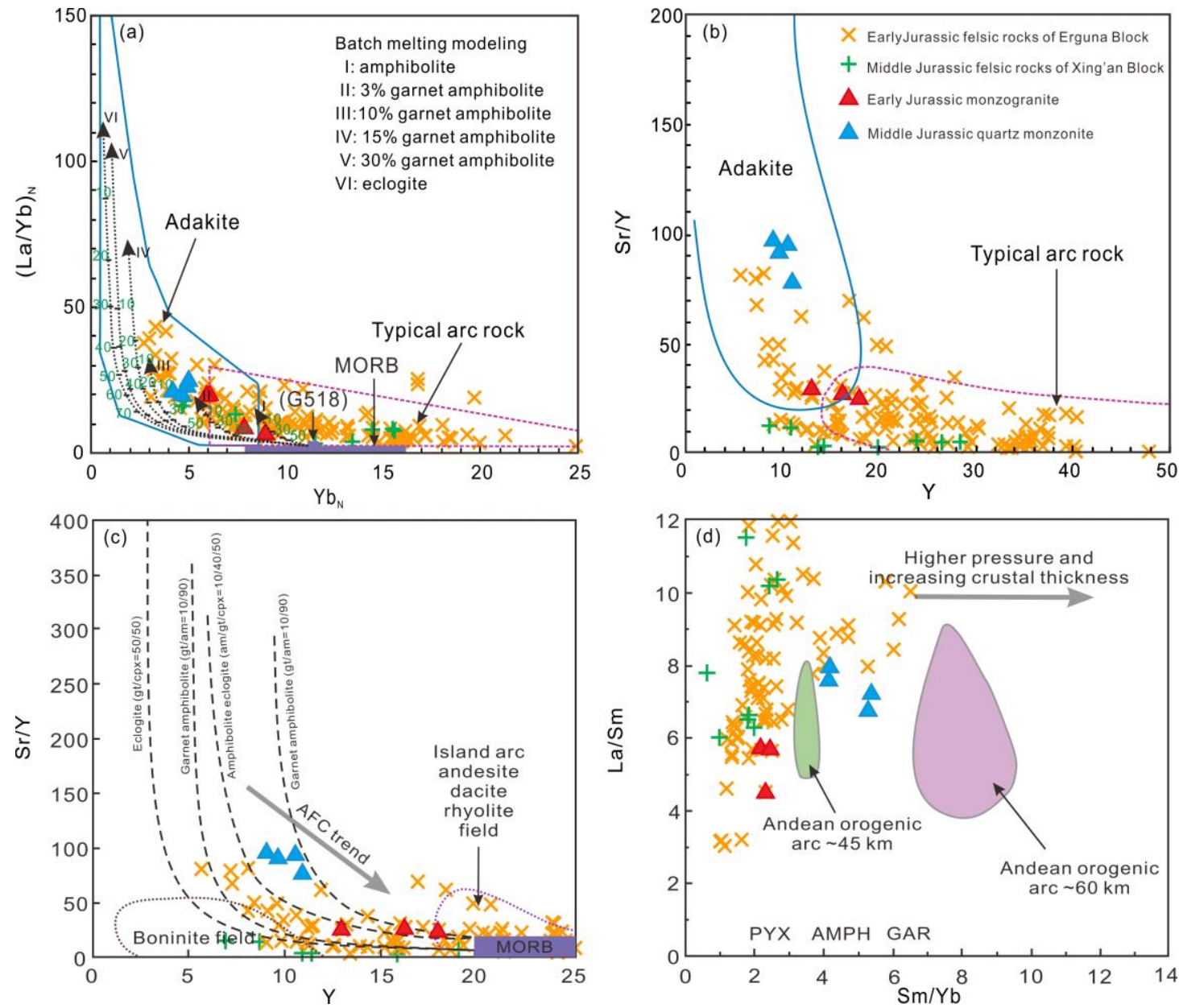

Figure 8. Plots of (a) chondrite-normalized $\mathrm{Yb}_{\mathrm{N}}$ versus $(\mathrm{La} / \mathrm{Yb})_{\mathrm{N}} ;(\mathbf{b}, \mathbf{c}) \mathrm{Y}$ versus $\mathrm{Sr} / \mathrm{Y} ;(\mathbf{d}) \mathrm{Sm} / \mathrm{Yb}$ versus La/Sm ( $a$ is after Drummond et al. [48]; $b$ and c are after Defant and Drummond [44]; Data of magmatic rocks in the Andean orogenic arcs in d are from Asadi et al. [49]; chondrite values are from Sun and McDonough [37]). G518 is an Eastern Pontides gabbro employed as the source rock for the batch-melting modeling [50].

\subsection{Zircon $\mathrm{Lu}-\mathrm{Hf}$ Isotopes}

A total of 21 representative zircons from four selected samples were chosen for in situ Lu-Hf isotopic analyses. The obtained data are presented in Table S7.

The ${ }^{176} \mathrm{Hf} /{ }^{177} \mathrm{Hf}$ ratios of the nine analytical spots from the Early Jurassic monzogranites vary from 0.28255 to 0.28280 . Their $\varepsilon_{\mathrm{Hf}}(\mathrm{t})$ values and two-stage model ages $\left(\mathrm{T}_{\mathrm{DM} 2}\right)$ are between -4.1 to +4.8 and 918 to $1488 \mathrm{Ma}$, respectively (Figure 9). Twelve spot analyses from Middle Jurassic quartz monzonites yield ${ }^{176} \mathrm{Hf} /{ }^{177} \mathrm{Hf}$ ratios of 0.28257 to 0.28271 and $\varepsilon_{\mathrm{Hf}}(\mathrm{t})$ values of -3.6 to +1.6 . The corresponding $\mathrm{T}_{\mathrm{DM} 2}$ ages range from 1111 to $1444 \mathrm{Ma}$ (Figure 9). 


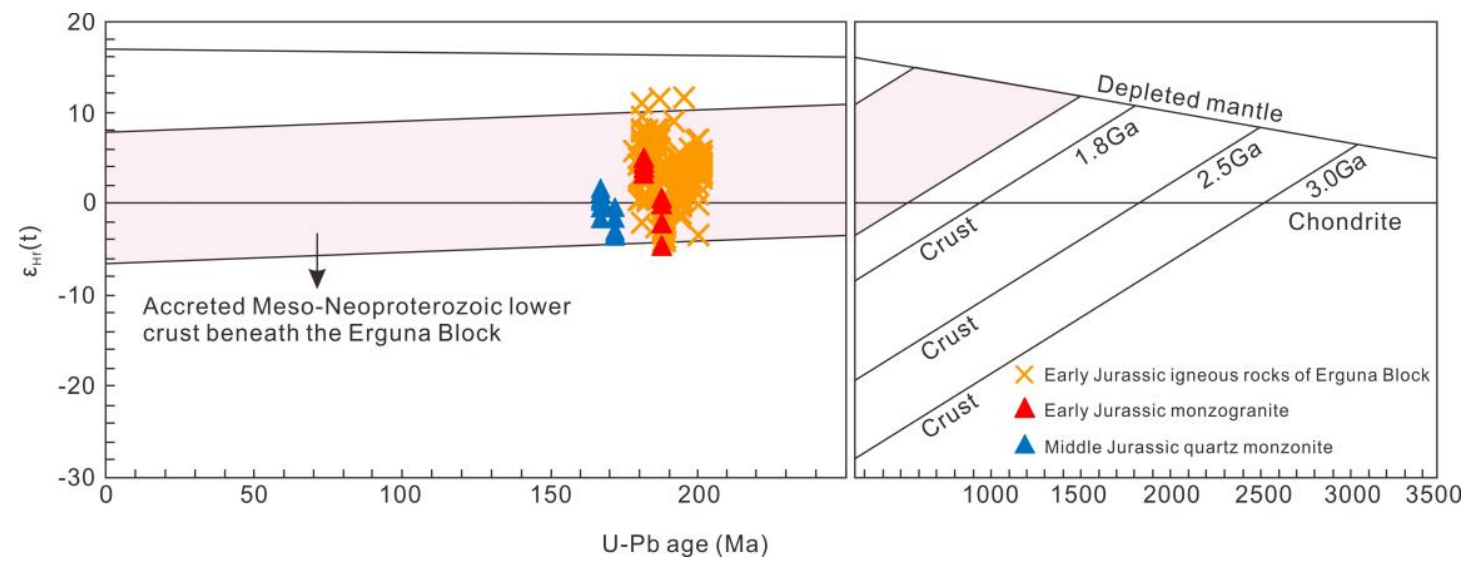

Figure 9. Zircon $\varepsilon_{\mathrm{Hf}}(\mathrm{t})$ versus $\mathrm{U}-\mathrm{Pb}$ age diagram for the Early-Middle Jurassic monzogranites and quartz monzonites from the Erguna Block. The shaded area represents the accreted Meso-Neoproterozoic lower crust beneath the Erguna Block (after Gou et al. [10]). The data for Early Jurassic igneous rocks of the Erguna Block are from references in Table S8. The data for Middle Jurassic igneous rocks are the first presented for the Erguna Block.

\section{Discussion}

\subsection{Petrogenesis}

\subsubsection{Early Jurassic Monzogranites}

Generally, granitoids are petrogenetically subdivided into I-, S-, A- and M-types [51-54]. In the study area, M-type affinity is firstly precluded due to the rare exposure of coeval and associated mafic rocks and ophiolites near the Early Jurassic monzogranites. The typical A-type granite is characterized by high $\left(\mathrm{Na}_{2} \mathrm{O}+\mathrm{K}_{2} \mathrm{O}\right)$ contents and $\mathrm{FeO}^{\mathrm{T}} / \mathrm{MgO}$ values [51]. In contrast, the studied monzogranites are subalkaline series on a TAS diagram (Figure 6a) with low $\left(\mathrm{Na}_{2} \mathrm{O}+\mathrm{K}_{2} \mathrm{O}\right)(6.78-8.97 \mathrm{wt} \%$ ) and $\mathrm{FeO}^{\mathrm{T}} / \mathrm{MgO}(1.85-3.23)$ values. Besides, A-type granites commonly exhibit high $\mathrm{Zr}, \mathrm{Nb}, \mathrm{Ta}, \mathrm{Ce}, \mathrm{Yb}$, and $\mathrm{Y}$ contents, as well as $\mathrm{Ga} / \mathrm{Al}$ ratios $[51,55,56]$. The monzogranites from the study area have low concentrations of these trace elements and fall into I- and S-type granites fields when plotted on both $(\mathrm{Zr}+\mathrm{Nb}+\mathrm{Ce}+\mathrm{Y})$ versus $\left.\left(\left(\mathrm{K}_{2} \mathrm{O}+\mathrm{Na}_{2} \mathrm{O}\right) / \mathrm{CaO}\right)\right)$ and $(\mathrm{Zr}+\mathrm{Nb}+\mathrm{Ce}+\mathrm{Y})$ versus $\left(\mathrm{FeO}^{\mathrm{T}} / \mathrm{MgO}\right)$ diagrams (Figure 10a,b). Furthermore, the $T_{\mathrm{Zr}}$ values of the Early Jurassic monzogranites $\left(771-790^{\circ} \mathrm{C}\right.$ ) are lower than A-type granites $\left(\sim 839^{\circ} \mathrm{C}\right)$, and similar to unfractionated I-type granites $\left(\sim 781^{\circ} \mathrm{C}\right)[39,57,58]$. The monzogranite samples are mineralogically characterized by the occurrence of amphibole and biotite (typical of I-type granites) and the absence of Al-rich and alkaline minerals, such as muscovite, cordierite, tourmaline, and corundum (typical of S-type granites) [59,60].

Early Jurassic monzogranites are widespread in the Erguna Block (Figure 1c) $[7,11,13]$. As shown on the petrogenetic discrimination diagrams, these monzogranites and other coeval felsic rocks are dominated by I-type geochemical affinity (Figure 10). These I-type granites are possibly generated by diverse petrogenetic mechanisms, including (1) highly fractional crystallization of mantle-originated mafic magma or mixing of mantle-originated magma and crustal materials [61,62]; or (2) partial melting of metaigneous rocks in the crust, followed by fractionation [63,64]. The formation of felsic rocks via the fractional crystallization of mantle-derived mafic magma usually demands the parental magma being voluminous [64]. The subordinate Early Jurassic mafic members in the Erguna Block preclude the possibility that the widespread monzogranites were originated by a simple fractional history. Besides, the $\mathrm{La} / \mathrm{Sm}$ and $\mathrm{Zr} / \mathrm{Nb}$ ratios of the studied samples increase with elevating $\mathrm{La}$ and $\mathrm{Zr}$ concentrations, respectively (Table S5), suggesting crustal partial melting played a significant role during the magma evolution. Therefore, we suggest that the partial melting of crustal metaigneous rocks was the dominant process responsible for the formation of the monzogranites. 

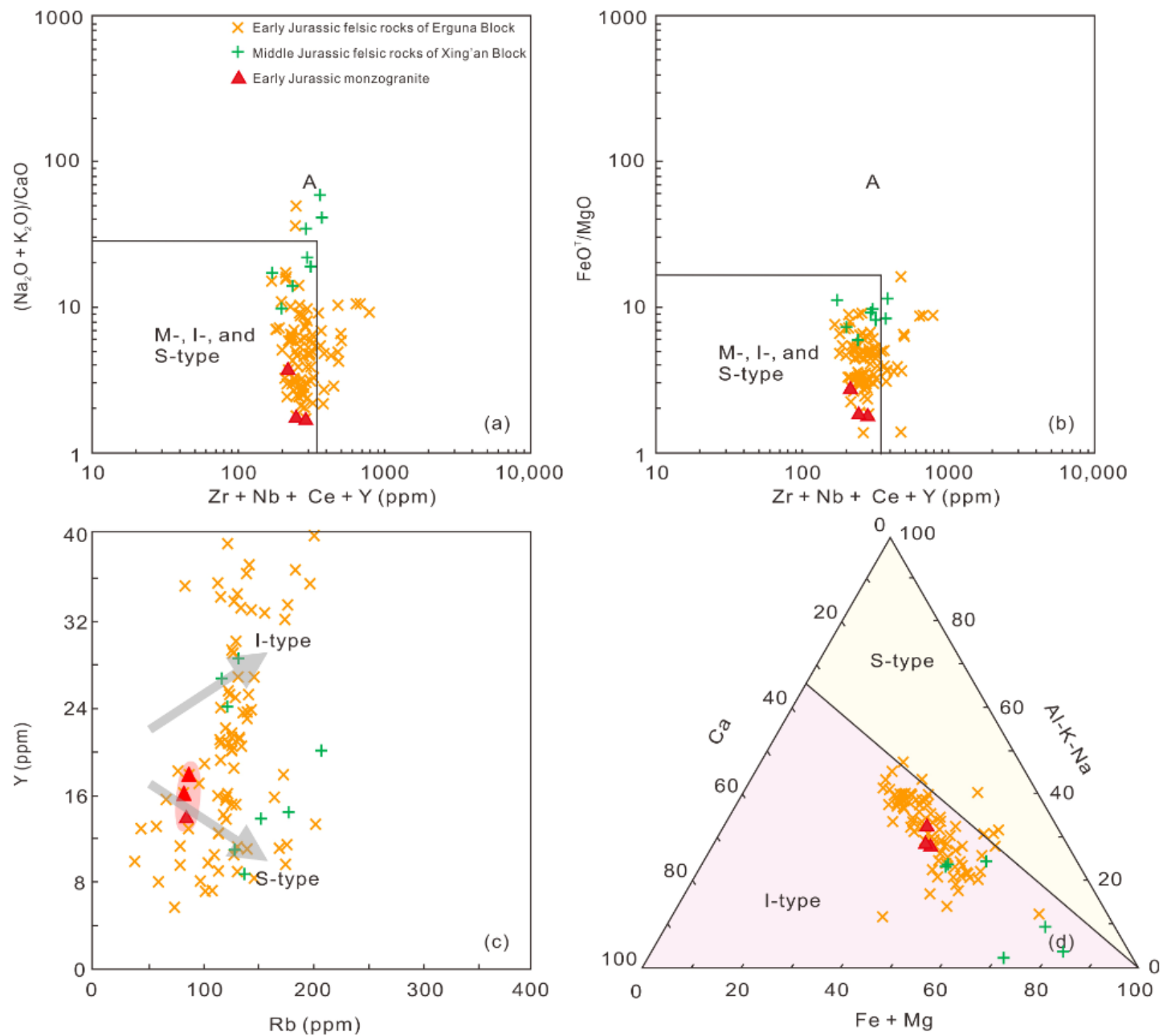

Figure 10. Petrogenetic discrimination diagrams for the Early-Middle Jurassic monzogranites and quartz monzonites from the Erguna Block. (a) $(\mathrm{Zr}+\mathrm{Nb}+\mathrm{Ce}+\mathrm{Y})$ versus $\left.\left(\left(\mathrm{K}_{2} \mathrm{O}+\mathrm{Na}_{2} \mathrm{O}\right) / \mathrm{CaO}\right)\right) ;(\mathbf{b})(\mathrm{Zr}$ $+\mathrm{Nb}+\mathrm{Ce}+\mathrm{Y}$ ) versus $\left(\mathrm{FeO}^{\mathrm{T}} / \mathrm{MgO}\right)$; (c) Rb versus $\mathrm{Y}$; (d) Al-Na-K-Ca-Fe+Mg ternary plot (a and b are after Whalen et al. [51]; $\mathrm{c}$ is after Chappell [52]; and $\mathrm{f}$ is after Chappell and White [55]).

As discussed above, the monzogranites from the study area are high-K calc-alkaline I-type granites. Melting experiments have demonstrated that high-K silicic melts can be generated by partial melting of tonalitic or granodioritic rocks [65]. The resulting melts geochemically would show A-type affinity, which is significantly inconsistent with our samples. Besides, if the rocks were derived by dehydration melting of tholeiitic amphibolites, they should exhibit low $\mathrm{K}_{2} \mathrm{O}$ concentrations and $\mathrm{Na}_{2} \mathrm{O} / \mathrm{K}_{2} \mathrm{O}$ values [66], which are distinct from the studied rocks. Experimental works have exhibited that the dehydration melting of slightly hydrous medium- to high-K basaltic rocks could generate high-K silicic melts [64]. The derived silicic melts are characterized by metaluminous to slightly peraluminous signatures, which are in good agreement with the monzogranites from the study area. Moreover, the monzogranites are depleted in HFSEs and HREEs, and exhibit high $\mathrm{Rb} / \mathrm{Sr}$ values $(0.19-0.27)$ and low zircon crystallization temperatures, implying a mica-bearing hydrous source $[67,68]$. They display moderate negative Eu anomalies with flat HREE patterns, and negative anomalies in $\mathrm{Sr}, \mathrm{Yb}, \mathrm{Y}$, and Ti. These geochemical characteristics indicate the involvement of plagioclase, hornblende, and garnet as major residual phases $[62,69]$. The leaving behind of a hornblende dominated residue by dehydration melting suggests that the magma source was possibly under 8-13 kbar and $700-800^{\circ} \mathrm{C}$ conditions ( $\leq 40 \mathrm{~km}$ depth) [70,71]. This is inconsistent with our calculated zircon saturation temperatures $\left(771-790{ }^{\circ} \mathrm{C}\right)$ and Ti-in zircon geothermometry $\left(755-900{ }^{\circ} \mathrm{C}\right.$ with most $\left.<800{ }^{\circ} \mathrm{C}\right)$. The zircons from the monzogranites experienced moderate primary high-T hydrothermal alteration 
during the deuteric stage of magma evolution (Figure $5 c, d$ ), with relatively good crystallinity of the rocks (Figure 2a,b), implying a deep intrusion depth of $\sim 5 \mathrm{~km}$. In a Sm/Yb versus La/Sm diagram (Figure 8d), the monzogranites and coeval felsic magmatic rocks in the Erguna Block plot in the field with a thickness thinner than $\sim 45-\mathrm{km}$-thick Andean orogenic arcs. Furthermore, batch-melting modeling displays that the parental magma of the monzogranites was formed in an environment where the P-T conditions are similar to garnet-amphibole-facies metamorphism, corresponding to a depth of $\leq 40 \mathrm{~km}$ [70] (Figure 8a,c).

The monzogranites have relatively high $\mathrm{Mg \#}$ values (49-56) and $\mathrm{MgO}$ concentrations $(0.76-2.13 \mathrm{wt} \%)$, which are indicative of interactions between the primary granitic melts and mantle materials. Minor mafic microgranular enclaves (MMEs) are locally found within the monzogranites, but mingling textures and complex compositional zoning in mafic minerals are seldom found, implying that the interactions were not extensive. In addition, the rocks also record a moderately scattered distribution of zircon $\varepsilon_{\mathrm{Hf}}(\mathrm{t})$ values between -4.1 to +4.8 with corresponding $\mathrm{T}_{\mathrm{DM} 2}$ ages of 918 to $1488 \mathrm{Ma}$ (Figure 9). The above field, geochemical, and isotopic signatures together indicate that the primary magma of the monzogranites was likely produced by partial melting of an accreted Meso-Neoproterozoic lower crust, with the injection of minor mantle components during the formation of the silicic magma. In conclusion, the Early Jurassic High-K calc-alkaline I-type monzogranites in the Erguna Block were likely derived by partial melting of K-rich meta-basalts within the lower part of a juvenile crust with medium-thickness.

\subsubsection{Middle Jurassic Quartz Monzonites}

In contrast to the Early Jurassic igneous rocks, Middle Jurassic magmatic rocks are rarely exposed in the Erguna Block and adjacent areas. The studied Middle Jurassic quartz monzonites are geochemically homogenous, they have $\mathrm{SiO}_{2}>56 \mathrm{wt} \%, \mathrm{Al}_{2} \mathrm{O}_{3}>15 \mathrm{wt} \%, 3.5 \mathrm{wt} \%<\mathrm{Na}_{2} \mathrm{O}<7.5 \mathrm{wt} \%, \mathrm{Y}<18 \mathrm{ppm}$, significantly high $\mathrm{Sr} / \mathrm{Y}$ values, and strong HFSEs depletions. These geochemical features are in excellent agreement with typical adakites. In both plots of chondrite-normalized $\mathrm{Yb}_{\mathrm{N}}$ versus $(\mathrm{La} / \mathrm{Yb})_{\mathrm{N}}$ and $\mathrm{Y}$ versus $\mathrm{Sr} / \mathrm{Y}$, the samples all fall into the adakite fields (Figure 8a,b). Previous researchers proposed different models explaining the derivation of adakitic rocks, including (1) magma mixing between silicic and mafic melts [72,73]; (2) partial melting of delaminated lower crust [48,74]; (3) assimilation and fractional crystallization (AFC) acting on primary mafic magmas $[75,76] ;(4)$ partial melting of a subducted oceanic slab [44,77]; or (5) partial melting of mafic rocks within thickened provenances of continental lower crust [45,78].

The quartz monzonites have a narrow range of $\varepsilon_{\mathrm{Hf}}(\mathrm{t})$ values $(-3.6$ to +1.6$)$, low $\mathrm{Mg} \#$ values $(36-44)$ and $\mathrm{MgO}$ concentrations (0.76-1.24 $\mathrm{wt} \%$ ), with lacking MMEs and mingling textures, suggesting that magma mixing is negligible. The classic delaminated lower crust-originated adakites commonly have high Mg\# values due to the involvement of mantle peridotite during magma ascending $[79,80]$. The low $\mathrm{Mg} \#$ values of our samples preclude the petrogenetic processes of partial melting of the delaminated lower crust. Minerals that account for AFC-generated adakitic rocks usually have high partition coefficients $\left(\mathrm{K}_{\mathrm{D}}\right)$ for $\mathrm{Y}$ and HREE, such as amphibole [75,76]. Amphibole fractionation is commonly coupled with the residue of plagioclase [81]. Besides, $K_{D}$ for middle-REEs is higher than HREE for amphibole $[82,83]$. Therefore, fractional crystallization of amphibole and plagioclase under a natural system would result in decreased $\mathrm{Dy} / \mathrm{Yb}$ ratios, and negative Eu anomalies with concave-upward REE trends for the leaving melts $[75,76]$. The studied quartz monzonites have constant $\mathrm{Dy} / \mathrm{Yb}$ ratios, negligible Eu anomalies with right-sloping REE patterns, indicating that AFC of primary basaltic magmas is insignificant. Besides, xenocrystic zircons, which are indicative of crustal assimilation during magma ascent and emplacement, were not found in the quartz monzonite samples, suggesting that the primary magma did not experience noteworthy crustal assimilation. The representative oceanic slab-originated adakitic rocks are characterized by low $\mathrm{Rb} / \mathrm{Sr}$ values $(0.01-0.04)$ and MORB-like $\mathrm{Lu}-\mathrm{Hf}$ isotopic signatures $[44,84]$. The studied quartz monzonites yield higher $\mathrm{Rb} / \mathrm{Sr}$ ratios of $0.05-0.09$, and distinctively lower $\varepsilon_{\mathrm{Hf}}(\mathrm{t})$ values between -1.3 to +1.6 in comparison with adakitic rocks originated 
from the oceanic slab. Moreover, slab-derived adakitic rocks are medium-K calc-alkaline series with high $\mathrm{Na}_{2} \mathrm{O} / \mathrm{K}_{2} \mathrm{O}$ values $(>2)[13,84]$. In contrast, the samples are high-K calc-alkaline rocks and show lower $\mathrm{Na}_{2} \mathrm{O} / \mathrm{K}_{2} \mathrm{O}$ ratios between 1.55-2.02. Thus, the partial melting of a subducted oceanic slab is unlikely.

Experimental works have indicated that basaltic melts in thickened regions of the continental lower crust commonly exhibit low Mg\# values $(<43)$ and $\mathrm{MgO}$ contents [45,63]. Similarly, the studied quartz monzonites show low Mg\# values (36-44) and $\mathrm{MgO}$ concentrations (0.76-1.24 wt\%). The batch melting model illustrates that the quartz monzonites likely originated from $\sim 10 \%-20 \%$ partial melting of an assumed $10 \%$ garnet-bearing amphibolite source (Figure $8 \mathrm{a})$. Besides, they have high $(\mathrm{Dy} / \mathrm{Yb})_{\mathrm{N}}$ ratios of $1.22-1.30(>1)$ and Sr concentrations of 847-1000 ppm (>400 ppm), but low $(\mathrm{La} / \mathrm{Sm})_{\mathrm{N}}$ ratios of $4.08-4.80$ $(<6)$ and $\mathrm{Yb}$ contents of $0.86-1.03 \mathrm{ppm}(<2 \mathrm{ppm})$, with negligible Eu anomalies, which strongly indicate that amphibolite and garnet are dominant residual phase [85]. The significant depletion of $\mathrm{Nb}$ and $\mathrm{Ta}$ implies the existence of rutile with garnet in the residual phase $[77,86]$. This is further supported by the Y versus Sr/Y plots (Figure 8c), which show that the parental provinces of the primary magma under P-T conditions similar to amphibole-eclogite-facies metamorphism. Therefore, the P-T conditions for the quartz monzonites are probably $>15 \mathrm{kbar}$ and $750-950^{\circ} \mathrm{C}$, corresponding to a depth of $\geq 50 \mathrm{~km}[70,86]$. This is in good agreement with our obtained zircon saturation temperatures $\left(782-806{ }^{\circ} \mathrm{C}\right)$. The Ti-in zircon geothermometry shows a relatively wide range of temperatures $\left(652-852{ }^{\circ} \mathrm{C}\right)$, which may imply complicated ascending and crystallization processes of the parental magma. Besides, the quartz monzonites exhibit a cumulate texture (Figure $2 \mathrm{~d}$ ). The thickened crust makes the magma to experience a long-distance ascending process before its final emplacement, with early crystallizing of amphiboles and plagioclases, followed by the protracted crystallizing of quartzs as the inter-cumulus phase. The zircons probably underwent moderate primary high-T hydrothermal alteration during the deuteric stage of magma evolution (Figure $5 c, d$ ). Combined with the relatively good crystallinity of the quartz monzonites (Figure 2c,d), a deep intrusion depth of $\sim 5 \mathrm{~km}$ may be constrained. In a Sm/Yb versus $\mathrm{La} / \mathrm{Sm}$ diagram (Figure $8 \mathrm{~d}$ ), the quartz monzonites plot between the $\sim 45$ - and $\sim 60-\mathrm{km}$-thick Andean orogenic arcs. Besides, the samples have relatively clustered $\varepsilon_{\mathrm{Hf}}(\mathrm{t})$ values and $\mathrm{T}_{\mathrm{DM} 2}$ ages range from -3.6 to +1.6 and 1111 to $1444 \mathrm{Ma}$, respectively (Figure 9), suggesting that they were possibly derived from the partial melting of an accreted Meso-Neoproterozoic lower crust. Thus, we suggest that the Middle Jurassic quartz monzonites with adakitic affinity in the Erguna Block were possibly generated by the partial melting of a thickened juvenile continental lower crust $(\geq 50 \mathrm{~km})$.

\subsection{Tectonic Setting and Geodynamic Scenario}

\subsubsection{Tectonic Regime}

NE China is tectonically situated in the eastern CAOB, which archives the Paleozoic-Mesozoic complex tectonic evolution of the Palaeo-Asian, Palaeo-Pacific, and Mongol-Okhotsk tectonic regimes $[1,23,86]$. The overprinting of multiple tectonic events results in debatable models for the tectonic history. The Early-Middle Jurassic tectonic settings for the intrusive rocks in the Erguna Block remain ambiguous, especially the Middle Jurassic, due to the poor exposure of magmatic rocks. The final closure of the Palaeo-Asian Ocean was probably finished before the Early Triassic along the Solonker-Xar Moron-Changchun-Yanji suture belt (Figure 1b) [1,9]. The resulting post-collisional Late Triassic bimodal magmatism and intrusions of A-type granitoids mainly occurred in the Lesser Xing'an and Zhangguangcai ranges, indicating an extensional setting [28,87]. The initiation of the westward subduction of the Palaeo-Pacific oceanic slab beneath the continental region of NE China was likely by the Late Triassic or Early Jurassic [88,89]. Subduction-related magmatism such as the Early Jurassic calc-alkaline volcanism in eastern Jilin-Heilongjiang provinces dominantly happened in eastern NE China [8]. The Erguna Block has geographically situated more than $900 \mathrm{~km}$ and $1000 \mathrm{~km}$ away from the Solonker-Xar Moron-Changchun-Yanji suture belt and the Palaeo-Pacific subduction zone, respectively. These long distances are generally considered to exceed the greatest 
extent of influence caused by far-field tectonics. On the contrary, the Erguna Block is located immediately to the southeast of the Mongol-Okhotsk suture belt, with a distance less than $200 \mathrm{~km}$. Moreover, the Paleozoic-Mesozoic magmatic activities in the Erguna Block show a NE-SW-trending, which well parallels to the Mongol-Okhotsk suture belt $[10,13,90]$. Consequently, the spatial distribution of magmatic rocks and tectonic locations of the Erguna Block indicate that the magmatism within the block was associated with neither the Paleo-Asian nor the Paleo-Pacific tectonic regimes. In addition, the impact of the Mongol-Okhotsk tectonic regime is suggested to extend at least as far as the eastern margin of the Xing'an Block, which lies in the southeast of the Erguna Block (Figure 1b) [12,91]. Thus, we consider that the Mongol-Okhotsk tectonic regime played a dominant role in accounting for the generation of the Early-Middle Jurassic intrusive rocks in the Erguna Block.

\subsubsection{Andean-Type Arc Setting for the Early Jurassic Monzogranites}

Huge volumes of Early Jurassic igneous sequences crop out in the Erguna Block (Figure 1c) [11,12]. The sequences are dominated by felsic and intermediate rocks, with minor mafic rocks, and belong to high-K calc-alkaline and calc-alkaline series (Figure 6). The studied monzogranites are geochemically high-K calc-alkaline I-type granites. Previous studies have shown that such granites may be produced in volcanic arc settings akin to the Andes, or post-collisional settings like the Caledonides [92]. The MOO is thought to have closed diachronously in a scissor-like manner from west to east due to the counterrotation of the Siberian Craton relative to the Mongolia-NE China continental blocks $[4,93,94]$. Some previous researches suggested that the closure of the MOO was by the Middle Jurassic $[4,7,11,14]$, while others argued that the completion was during the Late Jurassic-Early Cretaceous [13,15-17]. Although the timing of final closure is still controversial, the Erguna Block is considered to have been situated within an active margin setting dominated by the southward subduction of the MOOP during the Early Jurassic [7,10,12,95]. Moreover, recent studies have identified several subduction-related Early Jurassic Cu-Mo deposits in the Erguna Block, such as the Wunugetushan deposit (ca. 180 Ma) [94]. Therefore, the high-K calc-alkaline I-type monzogranites in the Erguna Block were not generated in a post-collisional setting such as the Caledonides. On tectonic setting discrimination diagrams of $(\mathrm{Yb}+\mathrm{Nb})$ versus $\mathrm{Rb},(\mathrm{Yb}+\mathrm{Ta})$ versus $\mathrm{Rb}, \mathrm{Y}$ versus $\mathrm{Nb}$, and the ternary plot of $\mathrm{Ta} \times 3-\mathrm{Rb} / 30-$ Hf (Figure 11a-d), all samples were plotted on the fields of volcanic granites, indicating a volcanic arc setting. Furthermore, previous works demonstrated that continental arc granites have relatively elevated Th and Ta concentrations in contrast to island arc granites [96-110]. The studied monzogranites contain Th and Ta similar to those felsic rocks from representative continental arc settings, such as Northern Andes [96,97], Colombian Caribbean area [98], and Colombian Andes [98], with compelling evidence from the $\mathrm{Ta} / \mathrm{Yb}$ versus $\mathrm{Th} / \mathrm{Yb}$ plot (Figure 11h), suggesting a continental arc setting. This is further evidenced by discriminant-function-based multi-dimensional robust diagrams (Figure 11e-g), where all samples were plotted on continental arc fields. The coeval felsic rocks within the Erguna Block also display identical features (Figure 11a-h). Thus, the Erguna Block was located in an Andean-type arc setting. A compressional environment was produced by continuous southward subduction of the MOOP beneath the trench. On a $\log \left[\mathrm{CaO} /\left(\mathrm{K}_{2} \mathrm{O}+\mathrm{Na}_{2} \mathrm{O}\right)\right]$ versus $\mathrm{SiO}_{2}$ diagram, all studied samples and most of the coexistent felsic rocks within the Erguna Block fall into the compressional fields (Figure 11i). The continental crust was relatively shortened to a medium thickness of appr. $\leq 40 \mathrm{~km}$. The heat bonus provided by the mantle wedge triggered the partial melting of K-rich meta-basalts within the lower part of a juvenile crust, resulting in the widespread high-K calc-alkaline magmatism in the Erguna Block. Notably, an Early Jurassic bimodal volcanism was observed in the east Songliao Basin, implying an extensional environment for the Palaeo-Pacific tectonic regime [8]. This is significantly different from the contemporary tectonic setting of the Erguna Block, further indicating that the Erguna Block was subjected to the Mongol-Okhotsk tectonic regime. 

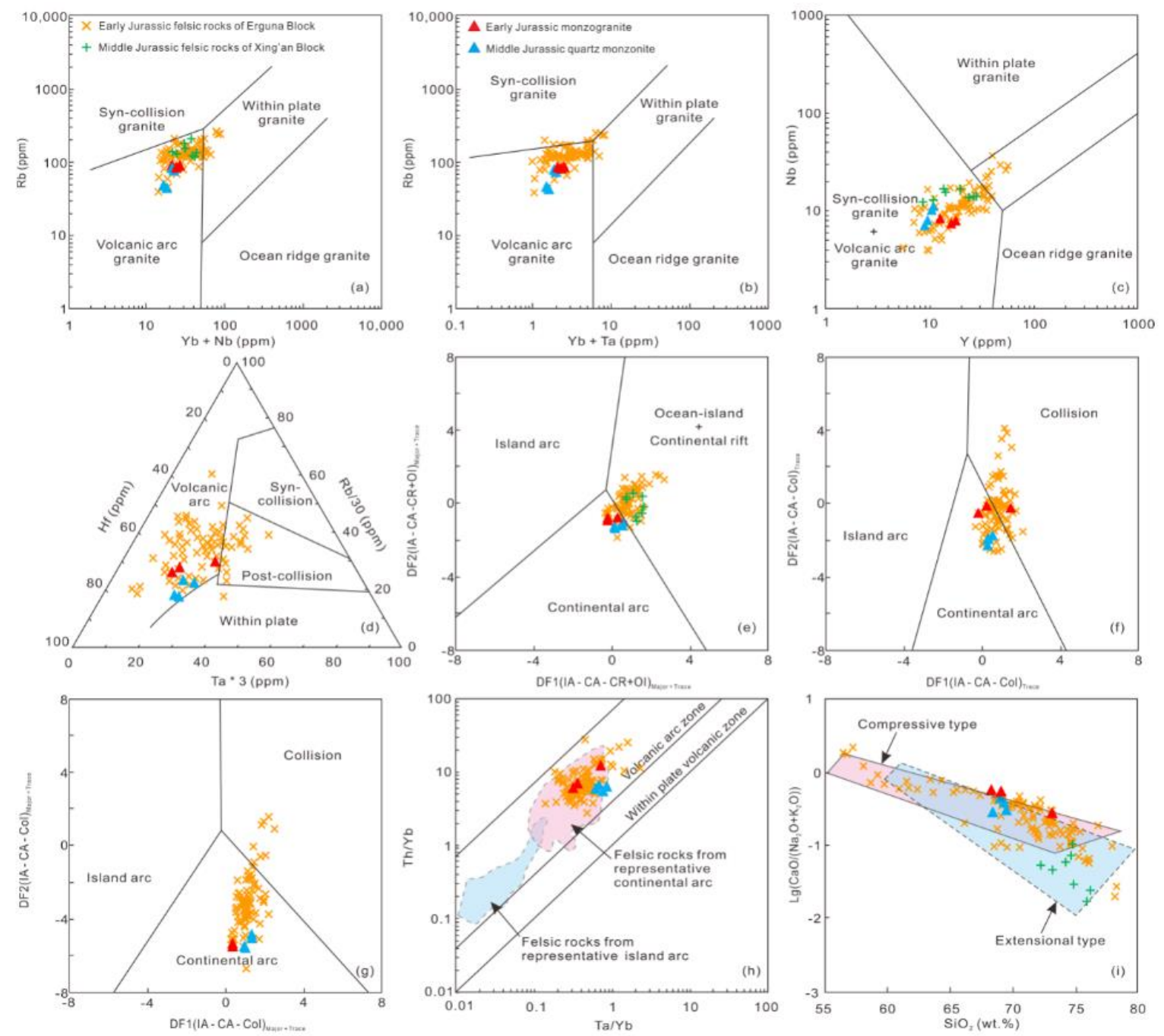

Figure 11. Tectonic setting discrimination diagrams for the Early-Middle Jurassic monzogranites and quartz monzonites from the Erguna Block. (a) $\mathrm{Yb}+\mathrm{Nb}$ versus $\mathrm{Rb}$; (b) $\mathrm{Yb}+\mathrm{Ta}$ versus $\mathrm{Rb}$; (c) Y versus $\mathrm{Nb}$; (d) DF1 (IA-CA-CR-OI) major + trace versus DF2 (IA-CA-CR-OI) major + trace; (e) DF1 (IA-CA-Col) trace versus DF2 (IA-CA-Col) trace; (f) DF1 (IA-CA-Col) major + trace versus DF2 (IA-CA-Col) major + trace; (g) $\mathrm{Ta} / \mathrm{Yb}$ versus $\mathrm{Th} / \mathrm{Yb}$; (h) $\mathrm{Ta} \times 3-\mathrm{Rb} / 30$ - Hf ternary plot; (i) $\mathrm{SiO}_{2}$ versus $\log \left(\mathrm{Cao} /\left(\mathrm{Na}_{2} \mathrm{O}+\mathrm{K}_{2} \mathrm{O}\right)\right.$ ). $((\mathbf{a}-\mathbf{c})$ are after Pearce et al. [100]; (d-f) are after Verma et al. [101]; (g) is after Gorton et al. [102]; (h) is after Harris et al. [103]; (i) is after Brown [104]). Felsic rocks of representative island arc are from Izu-Bonin-Mariana arc [105,106], Kermadec arc [107], Lesser Antilles arc [108], South Sandwich arc [109], and Tonga arc [110]. Felsic rocks of the representative continental include Northern Andes [96,97], Colombian Caribbean area [98], and Colombian Andes [99].

\subsubsection{Strong Crustal Thickening for the Middle Jurassic Quartz Monzonites}

Middle Jurassic igneous rocks are rarely observed in the Erguna Block and adjacent areas. The studied quartz monzonites have geochemical characteristics that are similar to adakitic rocks that originated from a thickened continental crust. The P-T conditions for the quartz monzonites correspond to a depth of $\geq 50 \mathrm{~km}$, indicating significant crustal shortening and thickening during the Middle Jurassic.

The quartz monzonites were produced in a volcanic arc setting, as evidenced by tectonic setting discrimination plots of $(\mathrm{Yb}+\mathrm{Nb})$ versus $\mathrm{Rb},(\mathrm{Yb}+\mathrm{Ta})$ versus $\mathrm{Rb}, \mathrm{Y}$ versus $\mathrm{Nb}$, and ternary plot of $\mathrm{Ta} \times 3-\mathrm{Rb} / 30$ - Hf (Figure 11a-d). Their elevated Th and Ta concentrations with respect to island arc igneous rocks imply a continental arc setting similar to the Early Jurassic monzogranites (Figure 11e-g). 
Moreover, all studied samples and most of the coeval felsic rocks within the Xing'an Block plot on the continental arc setting fields on the multi-dimensional robust diagrams (Figure 11e-g). We invoke, therefore, the Middle Jurassic quartz monzonites were generated in an Andean-type arc setting, similar to the Early Jurassic monzogranites. However, the continental crust of the Erguna Block was much uplifted during the Middle Jurassic in comparison with the Early Jurassic, as recorded by the distinctively different $\mathrm{P}-\mathrm{T}$ conditions of the monzogranites and quartz monzonites.

Notably, on a $\log \left[\mathrm{CaO} /\left(\mathrm{K}_{2} \mathrm{O}+\mathrm{Na}_{2} \mathrm{O}\right)\right]$ versus $\mathrm{SiO}_{2}$ diagram, the quartz monzonite samples plot on the transitional zone between the compressional and extensional fields, while the coexistent felsic rocks from the Xing' an Block fall into the extensional fields, which indicate a tectonic inversion. Moreover, in a $\mathrm{Sm} / \mathrm{Yb}$ versus La/Sm diagram (Figure $8 \mathrm{~d}$ ), these felsic rocks from the Xing'an Block plot on the field with a thickness thinner than $\sim 45-\mathrm{km}$-thick Andean orogenic arcs, which may imply back-arc extension in the southeast of the Erguna Block. In central Erguna Block, intermediate volcanic rock successions with zircon $\mathrm{U}-\mathrm{Pb}$ ages of ca. $162 \mathrm{Ma}$ exhibit a geochemical transition from sub-alkaline to alkaline series [8,111]. Besides, in the northern Erguna Block, A-type granites with zircon U-Pb ages of ca. 155 Ma was identified in the Badaguan area [4]. The above observations demonstrate that the Erguna Block has experienced a tectonic transition from compression to extension dominated by the southward subduction of the MOOP beneath the Erguna Block during the Middle Jurassic. Our quartz monzonites yielded zircon $\mathrm{U}-\mathrm{Pb}$ ages between ca. 162-174 Ma. Thus, we suggest that the significant crustal thickening may reach its ultimate stage at this time. The subsequent extensional environment dominated the formation of alkaline volcanic rocks and A-type granites.

\subsubsection{Geodynamic Scenario}

The closure of the MOO was completed by bidirectional-subduction beneath the Siberian Craton in the northwest and the Erguna and Xing'an blocks in the southeast $[6,13]$. The northward subduction of the MOOP could trace back to the Devonian [112]. The subduction-related magmatic activities in the Transbaikalia such as the Selenge arc archived persistent north-directed subduction from the Middle Carboniferous to the Triassic or Jurassic [92,112]. The southward subduction was initiated since the Carboniferous as evidenced by the Middle Gobi arc [113], followed by widespread Permo-Triassic subduction-related magmatic activities in the Central Mongolia, Erguna, and Xing'an blocks [12,13,31]. During the Early Jurassic, the continued subduction of the MOOP triggered the initiation of crustal thickening, accompanied by the intrusion of high-K calc-alkaline I-type monzogranites in the Erguna Block at ca. 177-198 Ma (Figure 12). Thus, the petrogenesis of the huge volumes of Early Jurassic magmatic rocks in the Erguna Block and adjacent areas were possibly dominated by an Andean-type continental arc environment (Figure 13a).

A significant magmatic quiescent is observed in the Great Xing'an Range, NE China, spanning from ca. 172-177 Ma (Figure 12). Several tectonic scenarios may account for such a magmatic gap, including (1) final closure of the ocean basin; (2) low-angle plate subduction; (3) mid-ocean ridge subduction; or (4) slab-rollback. Previous studies suggested that the MOO remained several thousand kilometers in width in the northwest of the Erguna Block during the Early Jurassic [16]. Besides, the studied Middle Jurassic quartz monzonites are typical adakitic rocks derived from an active continental margin. The Middle Jurassic granites within the Xing'an Block are high-K calc-alkaline I-type granites, indicating a subduction-related origin [12]. Moreover, a Late Jurassic (ca. $150 \mathrm{Ma}$ ) subduction-related Fukeshan $\mathrm{Cu}-\mathrm{Mo}$ deposit was identified within the Erguna Block recently [13]. Thus, the scenario (1) could be precluded. 


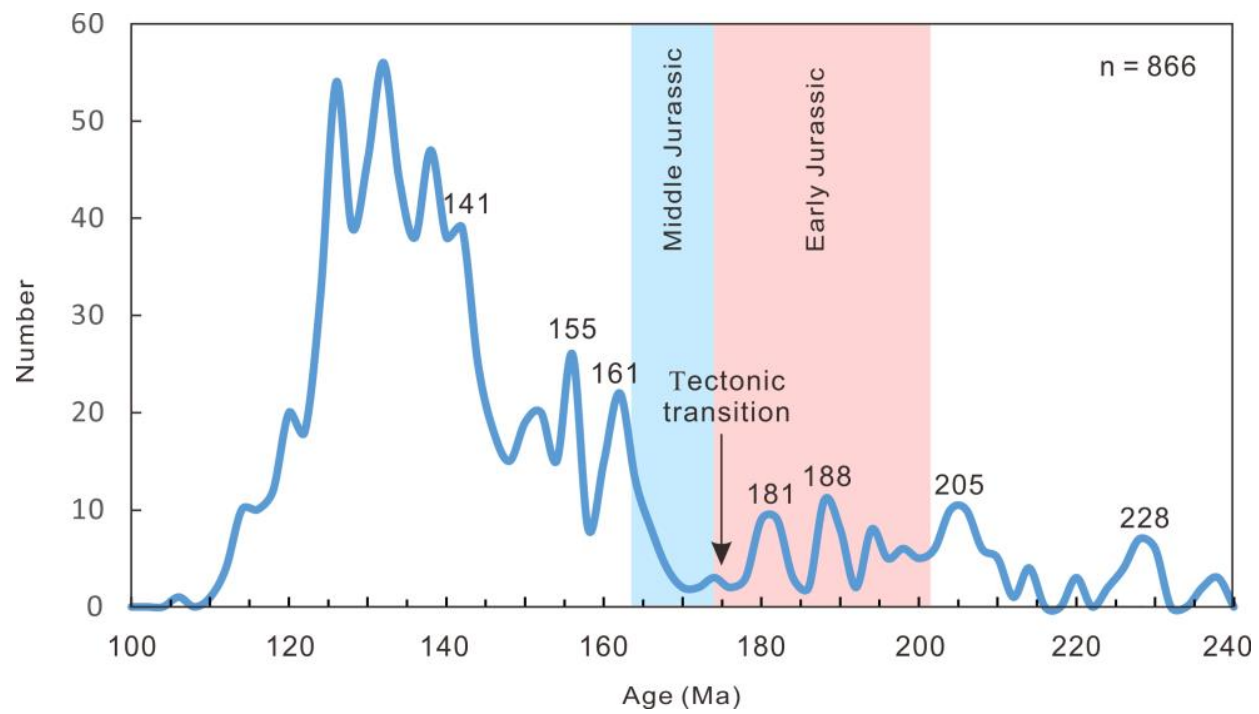

Figure 12. Probability plot of isotopic ages of Mesozoic igneous rocks in the Great Xing'an Range and surrounding areas. Data are listed in Table S1.

(a) Early Jurassic (198-177 Ma)

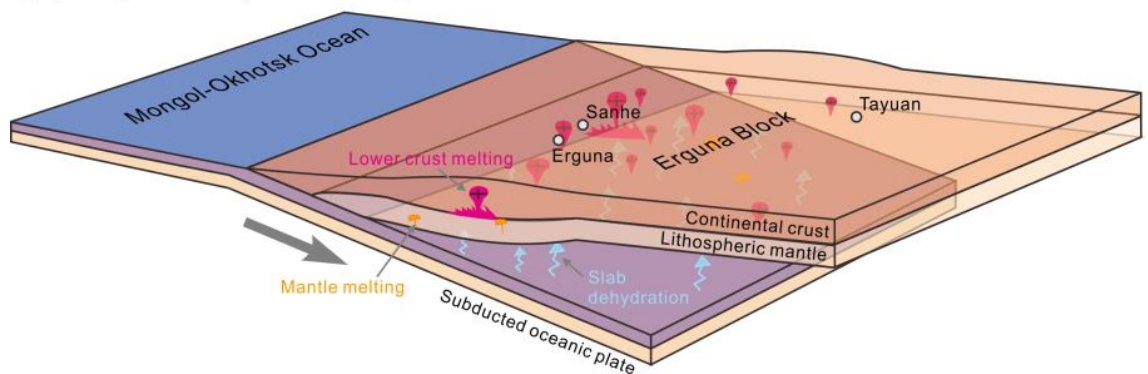

(b) late Early Jurassic-early Middle Jurassic (177-174 Ma)

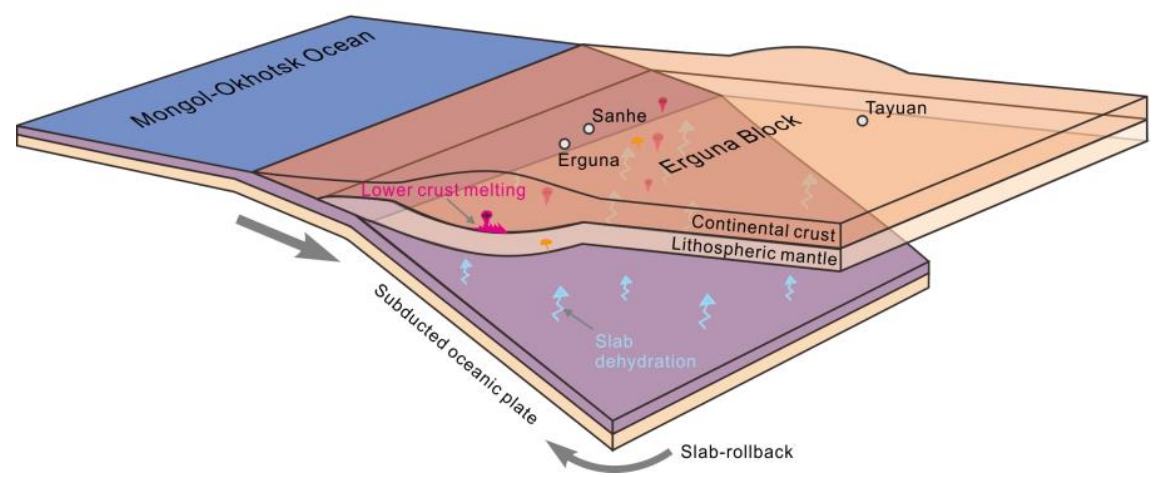

Figure 13. Schematic model illustrating the petrogenesis and tectonic setting of the Early-Middle Jurassic granitoids.

Subduction with a steep angle usually leads to a thick mantle wedge which motivates intense interactions between mantle materials, slab melts, and crustal rocks, and provides high thermal input $[77,114]$. In contrast, subduction with a low angle commonly produce an uneffective mantle wedge, and the far extended subducted-slab may hinder the conduction of heat from the mantle to the overriding crust $[115,116]$. The lithosphere would be consequently cooled, with suppression of magmatic activities. Mid-ocean ridge subduction may greatly shallow the subduction angle and cause a magmatic lull [117]. Subsequently, the buoyant oceanic topographic rises would result in the formation of a slab window, leading to a protracted magmatic activity represented by mafic and adakitic lavas 
near the trench $[118,119]$. Thus, both the low-angle plate subduction and mid-ocean ridge subduction are characterized by a shallowed subduction angle. Previous studies have demonstrated that low-angle subduction would greatly hamper the crustal thickening by forming an "eroding" margin at given stable conditions (medium rate orthogonal subduction), such as the Central American trench [18,120]. This is hard to reconcile with the case of the Erguna Block. As discussed above, the continental crust in the Middle Jurassic was significantly thicker than in the Early Jurassic, strongly indicating steep subduction. Besides, the slab window formed by mid-ocean ridge subduction would cause extensive magmatism with mafic rocks immediately after the magmatic quiescent period, contrasting with the observations in the Erguna Block. Therefore, the rollback of the subducted MOOP is the most plausible scenario that accounts for the magmatic gap.

The slab-rollback may start at ca. $177 \mathrm{Ma}$, the long-term persistent subduction resulted in the continuous growth of the continental crust in the Erguna Block. On the other hand, the gradual removal of thermal input from the mantle wedge cooled the lithosphere. The slab-rollback was terminated at ca. $174 \mathrm{Ma}$, accompanied by moderate magmatic activities that are characterized by adakitic rocks and high-K calc-alkaline I-type granites [12] (Figure 13b). The subduction-related crustal thickening may reach its ultimate stage at the same time. The consequent collapse triggered an extensional environment, resulting in the formation of alkaline volcanic sequences and A-type granitoids in the Erguna and Xing'an blocks [8,111]. The final closure of the MOO may be accomplished later at ca. 143-145 Ma [13,90], corresponding to a magmatic gap followed by intense post-collisional magmatism observed in the Great Xing' an Range (Figure 12).

\section{Conclusions}

1. Early Jurassic (ca. 177-198 Ma) high-K calc-alkaline I-type monzogranites, and Middle Jurassic (ca. 162-174 Ma) quartz monzonites with adakitic affinity were identified in the Erguna Block, NE China.

2. The Early Jurassic I-type monzogranites were likely originated by partial melting of K-rich meta-basalts from the lower part of a juvenile crust with medium-thickness $(\leq 40 \mathrm{~km})$, with the injection of minor mantle materials. The Middle Jurassic quartz monzonites were probably produced by partial melting of a thickened juvenile continental lower crust $(\geq 50 \mathrm{~km})$.

3. The Mongol-Okhotsk tectonic regime played a dominant role in accounting for the generation of the Early-Middle Jurassic intrusive rocks within the Erguna Block. An Andean-type continental arc setting was developed during the Early-Middle Jurassic, with continuous thickening of the continental crust. The significant crustal thickening may reach its peak during ca. 162-174 Ma, which marks the tectonic transition from compression to extension.

4. The MOOP was subducted southward beneath the Erguna Block during the Early Jurassic, followed by slab-rollback since ca. $178 \mathrm{Ma}$. The slab-rollback was terminated at ca. $174 \mathrm{Ma}$, accompanied by moderate magmatic activities represented by adakitic rocks.

Supplementary Materials: The following are available online at http://www.mdpi.com/2075-163X/10/4/372/s1, Analytical Techniques; Table S1: Locations and major mineral components of the Early-Middle Jurassic intrusive rocks of this study; Table S2: Radiometric ages of Late Triassic to Early Cretaceous igneous rocks in the Great Xing'an Range (NE China) and surrounding areas; Table S3: Zircon U-Pb isotopic data of the Early-Middle Jurassic intrusive rocks of this study; Table S4: Zircon trace element compositions (ppm) of the Early-Middle Jurassic intrusive rocks of this study; Table S5: Major (wt\%) and trace element (ppm) contents of the Early-Middle Jurassic intrusive rocks of this study; Table S6: Major ( $\mathrm{wt} \%)$ and trace element (ppm) contents of the Early Jurassic igneous rocks from the Erguna Block, and Middle Jurassic igneous rocks from the Xing'an Block, NE China; Table S7: Zircon Hf isotopic data of the Early-Middle Jurassic intrusive rocks of this study; Table S8: Zircon Hf isotopic data from Early Jurassic igneous rocks in the Erguna Block, NE China; Table S9: Metadata for LA-ICPMS zircon $\mathrm{U}-\mathrm{Pb}$ and trace element analyses of this study; Table S10: Metadata for whole-rock trace element analyses of this study; Table S11. Metadata for zircon Lu-Hf isotopic analyses of this study; Figure S1: Plot of zircon crystallization temperature and zircon saturation temperature. 
Author Contributions: Conceptualization, A.M. and D.S.; Methodology, A.M. and J.G.; Validation, D.S.; Formal Analysis and Data Curation, H.Z.; Project Administration, D.S.; Writing-original draft, A.M. All authors have read and agreed to the published version of the manuscript.

Funding: This research was funded by the Self Determined Foundation of Key Laboratory of Mineral Resources Evaluation in Northeast Asia, Ministry of Natural Resources of China (Grants DBY-ZZ-19-11 and DBY-ZZ-19-20); China Nuclear Geology (Grants 201467 and 201802).

Acknowledgments: We would like to thank three anonymous reviewers for detailed and constructive comments that greatly improved the manuscript. We thank the editors for their assistance, and Jonathan Pham for his help with the English of the manuscript.

Conflicts of Interest: The authors declare no conflict of interest.

\section{References}

1. Zhou, J.B.; Wilde, S.A.; Zhao, G.C.; Han, J. Nature and assembly of microcontinental blocks within the Paleo-Asian Ocean. Earth-Sci. Rev. 2017. [CrossRef]

2. Kelty, T.K.; Yin, A.; Dash, B.; Gehrels, G.E.; Ribeiro, A.E. Detrital-zircon geochronology of Paleozoic sedimentary rocks in the Hangay-Hentey basin, north-central Mongolia: Implications for the tectonic evolution of the Mongol-Okhotsk Ocean in central Asia. Tectonophysics 2008, 451, 290-311. [CrossRef]

3. Ruppen, D.; Knaf, A.; Bussien, D.; Winkler, W.; Chimedtseren, A.; von Quadt, A. Restoring the Silurian to carboniferous northern active continental margin of the Mongol-Okhotsk Ocean in Mongolia: Hangay-Hentey accretionary wedge and seamount collision. Gondwana Res. 2014, 25, 1517-1534. [CrossRef]

4. Tang, J.; Xu, W.L.; Wang, F.; Zhao, S.; Li, Y. Geochronology, geochemistry, and deformation history of Late Jurassic-Early Cretaceous intrusive rocks in the Erguna Massif, NE China: Constraints on the late Mesozoic tectonic evolution of the Mongol-Okhotsk orogenic belt. Tectonophysics 2015, 658, 91-110. [CrossRef]

5. Tomurtogoo, O.; Windley, B.F.; Kroner, A.; Badarch, G.; Liu, D.Y. Zircon age and occurrence of the Adaatsag ophiolite and Muron shear zone, central Mongolia: Constraints on the evolution of the Mongol-Okhotsk ocean, suture and orogen. J. Geol. Soc. 2005, 162, 125-134. [CrossRef]

6. Donskaya, T.V.; Gladkochub, D.P.; Mazukabzov, A.M.; De Waele, B.; Presnyakov, S.L. The late Triassic Kataev volcanoplutonic association in western Transbaikalia, a fragment of the active continental margin of the Mongol-Okhotsk Ocean. Russ. Geol. Geophys. 2012, 53, 22-36. [CrossRef]

7. Sun, D.Y.; Gou, J.; Wang, T.H.; Ren, Y.S.; Liu, Y.J.; Guo, H.Y.; Liu, X.M.; Hu, Z.C. Geochronological and geochemical constraints on the Erguna massif basement, NE China-subduction history of the Mongol-Okhotsk oceanic crust. Int. Geol. Rev. 2013, 55, 1801-1816. [CrossRef]

8. Xu, W.L.; Pei, F.P.; Wang, F.; Meng, E.; Ji, W.Q.; Yang, D.B.; Wang, W. Spatial-temporal relationships of Mesozoic volcanic rocks in NE China: Constraints on tectonic overprinting and transformations between multiple tectonic regimes. J. Asian Earth Sci. 2013, 74, 167-193. [CrossRef]

9. Wu, F.Y.; Sun, D.Y.; Ge, W.C.; Zhang, Y.B.; Grant, M.L.; Wilde, S.A.; Jahn, B.M. Geochronology of the Phanerozoic granitoids in northeastern China. J. Asian Earth Sci. 2011, 41, 1-30. [CrossRef]

10. Gou, J.; Sun, D.Y.; Qin, Z. Late Jurassic-Early Cretaceous tectonic evolution of the Great Xing'an Range: Geochronological and geochemical evidence from granitoids and volcanic rocks in the Erguna Block, NE China. Int. Geol. Rev. 2019, 61, 1842-1863. [CrossRef]

11. Gou, J.; Sun, D.Y.; Ren, Y.S.; Hou, X.G.; Yang, D.G. Geochemical and Hf isotopic compositions of Late Triassic-Early Jurassic intrusions of the Erguna Block, Northeast China: Petrogenesis and tectonic implications. Int. Geol. Rev. 2017, 59, 347-367. [CrossRef]

12. Liu, H.C.; Li, Y.L.; He, H.Y.; Huangfu, P.P.; Liu, Y.Z. Two-phase southward subduction of the Mongol-Okhotsk oceanic plate constrained by Permian-Jurassic granitoids in the Erguna and Xing'an massifs (NE China). Lithos 2018, 304-307, 347-361. [CrossRef]

13. Deng, C.Z.; Sun, D.Y.; Han, J.S.; Chen, H.Y.; Li, G.H.; Xiao, B.; Li, R.C.; Feng, Y.Z.; Li, C.L.; Lu, S. Late-stage southwards subduction of the Mongol-Okhotsk oceanic slab and implications for porphyry $\mathrm{Cu}-\mathrm{Mo}$ mineralization: Constraints from igneous rocks associated with the Fukeshan deposit, NE China. Lithos 2019, 326-327, 341-357. [CrossRef]

14. Li, Y.; Ding, L.L.; Xu, W.L.; Wang, F.; Tang, J.; Zhao, S.; Wang, Z.J. Geochronology and geochemistry of muscovite granite in Sunwu area, NE China: Implications for the timing of closure of the Mongol-Okhotsk Ocean. Acta Petrol. Sin. 2015, 31, 56-66. (In Chinese with English Abstract). 
15. Metelkin, D.V.; Vernikovsky, V.A.; Kazansky, A.Y.; Wingate, M.T.D. Late Mesozoic tectonics of Central Asia based on paleomagnetic evidence. Gondwana Res. 2010, 18, 400-419. [CrossRef]

16. Pei, J.; Sun, Z.; Liu, J.; Liu, J.; Wang, X.; Yang, Z.; Zhao, Y.; Li, H. A paleomagnetic study from the late Jurassic volcanics (155 Ma), North China: Implications for the width of Mongol-Okhotsk Ocean. Tectonophysics 2011, 510, 370-380.

17. Yang, Y.T.; Guo, Z.X.; Song, C.C.; Li, X.B.; He, S. A short-lived but significant Mongol-Okhotsk collisional orogeny in latest Jurassic-earliest Cretaceous. Gondwana Res. 2015, 28, 1096-1116. [CrossRef]

18. Safonova, I.Y.; Santosh, M. Accretionary complexes in the Asia Pacifc region: Tracing archives of ocean plate stratigraphy and tracking mantle plumes. Gondwana Res. 2014, 25, 126-158. [CrossRef]

19. Xiao, W.J.; Windley, B.F.; Hao, J.; Zhai, M.G. Accretion leading to collision and the Permian Solonker suture, Inner Mongolia, China: Termination of the central Asian orogenic belt. Tectonics 2003, 22, 1069-1089. [CrossRef]

20. Jahn, B.M.; Wu, F.Y.; Chen, B. Massive granitoid generation in Central Asia: Nd isotope evidence and implication for continental growth in the Phanerozoic. Episodes 2000, 23, 82-92. [CrossRef]

21. Windley, B.F.; Alexeiev, D.; Xiao, W.J.; Kröner, A.; Badarch, G. Tectonic model for accretion of the Central Asian Orogenic Belt. J. Geol. Soc. Lond. 2007, 164, 31-47. [CrossRef]

22. Sengör, A.M.C.; Natal'in, B.A.; Burtman, V.S. Evolution of the Altaid tectonic collage and Palaeozoic crustal growth in Eurasia. Nature 1993, 364, 299-307. [CrossRef]

23. Liu, Y.J.; Li, W.M.; Feng, Z.Q.; Wen, Q.B.; Neubauer, F.; Liang, C.Y. A review of the Paleozoic tectonics in the eastern part of Central Asian Orogenic Belt. Gondwana Res. 2017, 43, 123-148. [CrossRef]

24. Zheng, H.; Sun, X.M.; Wan, K.; Wang, P.J.; He, S.; Zhang, X.Q. Structure and tectonic evolution of the Late Jurassic-Early Cretaceous Wandashan accretionary complex, NE China. Int. Geol. Rev. 2019, 61, 17-38. [CrossRef]

25. Ge, W.C.; Wu, F.Y.; Zhou, C.Y.; Abdel Rahman, A.A. Emplacement age of the Tahe granite and its constraints on the tectonic nature of the Erguna block in the northern part of the Da Xing'an Range. Chin. Sci. Bull. 2005, 50, 2097-2105. [CrossRef]

26. Inner Mongolian Bureau of Geology Mineral Resources. Regional Geology of Inner Mongolia; Geological Publishing House: Beijing, China, 1991; pp. 1-725. (In Chinese with English Abstract).

27. Miao, L.C.; Liu, D.Y.; Zhang, F.Q.; Fan, W.M.; Shi, Y.R.; Xie, H.Q. Zircon SHRIMP U-Pb ages of the "Xinghuadukou Group" in Hanjiayuanzi and Xinlin areas and the "Zhalantun Group" in Inner Mongolia, Da Hinggan mountains. Chin. Sci. Bull. 2007, 52, 1112-1134. [CrossRef]

28. Gou, J.; Sun, D.Y.; Liu, Y.J.; Ren, Y.S.; Zhao, Z.H.; Liu, X.M. Geochronology, petrogenesis, and tectonic setting of Mesozoic volcanic rocks, southern Manzhouli area, Inner Mongolia. Int. Geol. Rev. 2013, 55, 1029-1048. [CrossRef]

29. Zheng, H.; Sun, X.M.; Zhu, D.F.; Tian, J.X.; He, S.; Wang, Y.D.; Zhang, X.Q. The structural characteristics, age of origin, and tectonic attribute of the Erguna Fault, NE China. Sci. China Earth Sci. 2015, 58, 1553-1565. [CrossRef]

30. Zhang, L.C.; Zhou, X.M.; Ying, J.F.; Wang, F.; Guo, F.; Wan, B.; Chen, Z.G. Geochemistry and Sr-Nd-Pb-Hf isotopes of Early Cretaceous basalts from the Great Xinggan Range, NE China: Implications for their origin and mantle source characteristics. Chem. Geol. 2008, 256, 12-23. [CrossRef]

31. Kang, Y.J.; She, H.Q.; Lai, Y.; Wang, Z.Q.; Li, J.W.; Zhang, Z.H.; Xiang, A.P.; Jiang, Z.S. Evolution of Middle-Late Triassic granitic intrusions from the Badaguan Cu-Mo deposit, Inner Mongolia: Constraints from zircon $\mathrm{U}-\mathrm{Pb}$ dating, geochemistry and Hf isotopes. Ore Geol. Rev. 2018, 95, 195-215. [CrossRef]

32. Gao, B.Y.; Zhang, L.C.; Jin, X.D.; Li, W.J.; Chen, Z.G.; Zhu, M.T. Geochronology and geochemistry of the Badaguan porphyry $\mathrm{Cu}-\mathrm{Mo}$ deposit in Derbugan metallogenic belt of the NE China, and their geological significances. Int. J. Earth Sci. 2016, 105, 507-519. [CrossRef]

33. Zhao, Q.; Xiao, R.G.; Zhang, D.H.; Wang, J.P.; Zhang, Y.F.; Li, P.P. Petrogenesis and tectonic setting of ore-associated intrusive rocks in the Baiyinnuoer $\mathrm{Zn}-\mathrm{Pb}$ deposit, southern Great Xing'an Range (NE China): Constraints from zircon $\mathrm{U}-\mathrm{Pb}$ dating, geochemistry, and $\mathrm{Sr}-\mathrm{Nd}-\mathrm{Pb}$ isotopes. Minerals 2020, 10, 19. [CrossRef]

34. Xu, L.Q.; Liu, C.; Deng, J.F.; Li, N.; Dai, M.; Bai, L.B. Geochemical characteristics and zircon U-Pb SHRIMP age of igneous rocks in Erentaolegai silver deposit, Inner Mongolia. Acta Petrol. Sin. 2014, 30, 3203-3212. (In Chinese with English Abstract). 
35. Streckeisen, A. Classification and nomenclature of plutonic rocks. Geologische Rundschau 1974, 63, 773-786. [CrossRef]

36. Hoskin, P.W.O. Trace-element composition of hydrothermal zircon and the alteration of hadean zircon from the jack hills, Australia. Geochim. Cosmochim. Acta 2005, 69, 637-648. [CrossRef]

37. Sun, S.S.; McDonough, W.F. Chemical and isotopic systematics of oceanic basalts; implications for mantle composition and processes. Geol. Soc. Lond. Spec. Publ. 1989, 42, 313-345. [CrossRef]

38. Ferry, J.; Watson, E. New thermodynamic models and revised calibrations for the Ti-in-zircon and Zr-in-rutile thermometers. Contrib. Miner. Petrol. 2007, 154, 429-437. [CrossRef]

39. Watson, E.B.; Harrison, T.M. Zircon saturation revisited: Temperature and composition efects in a variety of crustal magma types. Earth Planet. Sci. Lett. 1983, 64, 295-304. [CrossRef]

40. Watson, E.B.; Harrison, T.M. Zircon thermometer reveals minimum melting conditions on earliest Earth. Science 2005, 308, 841-844. [CrossRef]

41. Irvine, T.N.; Baragar, W.R.A. A guide to the chemical classification of the common volcanic rocks. Can. J. Earth Sci. 1971, 8, 523-548. [CrossRef]

42. Peccerillo, A.; Taylor, S.R. Geochemistry of Eocene calc-alkaline volcanic rocks from the Kastamonu Area, Northern Turkey. Contrib. Miner. Petrol. 1976, 58, 63-81. [CrossRef]

43. Maniar, P.D.; Piccoli, P.M. Tectonic discrimination of granitoids. Geol. Soc. Am. Bull. 1989, 101, $635-643$. [CrossRef]

44. Defant, M.J.; Drummond, M.S. Derivation of some modern arc magmas by melting of young subducted lithosphere. Nature 1990, 347, 662-665. [CrossRef]

45. Atherton, M.P.; Petford, N. Generation of sodium-rich magmas from newly underplated basaltic crust. Nature 1993, 362, 144-146. [CrossRef]

46. Kay, R.W.; Kay, S.M. Delamination and delamination magmatism. Tectonophysics 1993, 219, 177-189. [CrossRef]

47. Boynton, W.V. Cosmochemistry of the rare earth elements: Meteorite studies. Dev. Geochem. 1984, 2, 63-114.

48. Drummond, M.S.; Defant, M.J.; Kepezhinskas, P.K. Petrogenesis of slab-derived trondhjemite-tonalite-dacite/adakite magmas. Trans. R. Soc. Edinb. Earth Sci. 1996, 87, 205-215.

49. Asadi, S.; Moore, F.; Zarasvandi, A. Discriminating productive and barren porphyry copper deposits in the southeastern part of the central Iranian volcano-plutonic belt, Kerman region, Iran: A review. Earth-Sci. Rev. 2014, 138, 25-46. [CrossRef]

50. Dokuz, A.; Tanyolu, E.; Genc, S. A mantle- and a lower crust-derived bimodal suite in the Yusufeli (Artvin) area, NE Turkey: Trace element and REE evidence for subduction-related rift origin of early Jurassic Demirkent intrusive complex. Int. J. Earth Sci. 2006, 95, 370-394. [CrossRef]

51. Whalen, J.B.; Currie, K.L.; Chappell, B.W. A-type granites: Geochemical characteristics, discrimination and petrogenesis. Contrib. Miner. Petrol. 1987, 95, 407-419. [CrossRef]

52. Chappell, B.W. Aluminium saturation in I- and S-type granites and the characterization of fractionated haplogranites. Lithos 1999, 46, 535-551. [CrossRef]

53. Frost, B.R.; Barnes, C.G.; Collins, W.J.; Arculus, R.J.; Ellis, D.J.; Frost, C.D. A geochemical classification for granitic rocks. J. Petrol. 2001, 42, 2033-2048. [CrossRef]

54. Champion, D.C.; Bultitude, R.J. The geochemical and $\mathrm{Sr}-\mathrm{Nd}$ isotopic characteristics of Paleozoic fractionated S-types granites of north Queensland: Implications for S-type granite petrogenesis. Lithos 2013, 162-163, 37-56. [CrossRef]

55. Chappell, B.W.; White, A.J.R. Two contrasting granite types: 25 years later. Aust. J. Earth Sci. 2001, 48, 489-499. [CrossRef]

56. Bonin, B. A-type granites and related rocks: Evolution of a concept, problems and prospects. Lithos 2007, 97, 1-29. [CrossRef]

57. Zheng, J.; Mao, J.; Chai, F.; Yang, F. Petrogenesis of Permian A-type granitoids in the Cihai iron ore district, Eastern Tianshan, NW China: Constraints on the timing of iron mineralization and implications for a non-plume tectonic setting. Lithos 2016, 260, 371-383. [CrossRef]

58. Sun, C.Y.; Tang, J.; Xu, W.L.; Li, Y.; Zhao, S. Crustal accretion and reworking processes of micro-continental massifs within orogenic belt: A case study of the Erguna Massif, NE China. Sci. China Earth Sci. 2017, 60, 1256-1267. [CrossRef] 
59. Barbarin, B. A review of the relationships between granitoid types, their origins and their geodynamic environments. Lithos 1999, 46, 605-626. [CrossRef]

60. Ghani, A.A.; Searle, M.; Robb, L.; Chung, S.L. Transitional I- S-type characteristic in the Main Range Granite, Peninsular Malaysia. J. Asian Earth Sci. 2013, 76, 225-240. [CrossRef]

61. Barth, A.P.; Wooden, J.L.; Tosdal, R.M.; Morrison, J. Crustal contamination in the petrogenesis of a calc-alkalic rock series-Josephine Mountain intrusion, California. Geol. Soc. Am. Bull. 1995, 107, 201-212. [CrossRef]

62. Topuz, G.; Altherr, R.; Siebel, W.; Schwarz, W.H.; Zack, T.; Hasözbek, A.; Barth, M.; Satır, M.; Şene, C. Carboniferous high-potassium I-type granitoid magmatism in the Eastern Pontides: The Gümüşhane pluton (NE Turkey). Lithos 2010, 116, 92-110. [CrossRef]

63. Rapp, R.P.; Watson, E.B. Dehydration melting of metabasalt at 8-32-Kbar implications for continental growth and crust-mantle recycling. J. Petrol. 1995, 36, 891-931. [CrossRef]

64. Sisson, T.; Ratajeski, K.; Hankins, W.; Glazner, A. Voluminous granitic magmas from common basaltic sources. Contrib. Miner. Petrol. 2005, 148, 635-661. [CrossRef]

65. Patiño Douce, A.E.; Beard, J.S. Dehydration-melting of Biotite Gneiss and Quartz Amphibolite from 3 to 15 kbar. J. Petrol. 1995, 36, 707-738. [CrossRef]

66. Li, X.H.; Li, Z.X.; Li, W.X.; Liu, Y.; Yuan, C.; Wei, G.J.; Qi, C.S. U-Pb zircon, geochemical and Sr-Nd-Hf isotopic constraints on age and origin of Jurassic I- and A-type granites from central Guangdong, SE China: A major igneous event in response to foundering of a subducted fat-slab? Lithos 2007, 96, 186-204. [CrossRef]

67. King, P.L.; White, A.J.R.; Chappell, B.W.; Allen, C.M. Characterization and origin of aluminous A-type granites from the Lachlan Fold Belt, Southeastern Australian. J. Petrol. 1997, 38, 371-391. [CrossRef]

68. Zhao, J.L.; Qiu, J.S.; Liu, L.; Wang, R.Q. The Late Cretaceous I- and A-type granite association of southeast China: Implications for the origin and evolution of postcollisional extensional magmatism. Lithos 2016, 240, 16-33. [CrossRef]

69. Hastie, A.R.; Kerr, A.C.; Mcdonald, I.; Mitchell, S.F.; Pearce, J.A.; Millar, I.L.; Barfod, D.; Mark, D.F. Geochronology, geochemistry and petrogenesis of rhyodacite lavas in eastern Jamaica: A new adakite subgroup analogous to early Archaean continental crust? Chem. Geol. 2010, 276, 344-359. [CrossRef]

70. Zhang, Q.; Wang, Y.; Li, C.D.; Wang, Y.L.; Jin, W.J.; Jia, X.Q. Granite classification on the basis of Sr and Yb contents and its implications. Acta Petrol. Sin. 2006, 22, 2249-2269. (In Chinese with English Abstract).

71. Qian, Q.; Hermann, J. Partial melting of lower crust at 10-15kbar: Constraints on adakite and TTG formation. Contrib. Miner. Petrol. 2013, 165, 1195-1224. [CrossRef]

72. Kemp, A.I.S.; Wormald, R.J.; Whitehouse, M.J.; Price, R.C. Hf isotopes in zircon reveal contrasting sources and crystallization histories for alkaline to peralkaline granites of Temora, southeastern Australia. Geology 2005, 33, 797-800. [CrossRef]

73. Yang, J.H.; Wu, F.Y.; Chung, S.L.; Wilde, S.A.; Chu, M.F. A hybrid origin for the Qianshan A-type granite, northeast China: Geochemical and Sr-Nd-Hf isotopic evidence. Lithos 2006, 89, 89-106. [CrossRef]

74. Wang, Q.; Wyman, D.A.; Xu, J.; Jian, P.; Zhao, Z.; Li, C.; Xu, W.; Ma, J.; He, B. Early Cretaceous adakitic granites in the Northern Dabie Complex, central China: Implications for partial melting and delamination of thickened lower crust. Geochim. Cosmochim. Acta 2007, 71, 2609-2636. [CrossRef]

75. Castillo, P.R.; Janney, P.E.; Solidum, R. Petrology and geochemistry of Camiguin Island, southern Philippines: Insights into the source of adakite and other lavas in a complex arc tectonic setting. Contrib. Miner. Petrol. 1999, 134, 33-51. [CrossRef]

76. Macpherson, C.G.; Dreher, S.T.; Thirlwall, M.F. Adakites without slab melting: High pressure differentiation of island arc magma, Mindanao, the Philippines. Earth Planet. Sci. Lett. 2006, 243, 581-593. [CrossRef]

77. Martin, H.; Smithies, R.H.; Rapp, R.; Moyen, J.F.; Champion, D. An overview of adakite, tonalite-trondhjemite-granodiorite (TTG), and sanukitoid: Relationships and some implications for crustal evolution. Lithos 2005, 79, 1-24. [CrossRef]

78. Wang, Q.; McDermott, F.; Xu, J.F.; Bellon, H.; Zhu, Y.T. Cenozoic K-rich adakitic volcanic rocks in the Hohxil area, northern Tibet: Lower-crustal melting in an intracontinental setting. Geology 2005, 33, 465-468. [CrossRef]

79. Xu, J.F.; Shinjo, R.; Defant, M.J.; Wang, Q.; Rapp, P.T. Origin of Mesozoic adakitic intrusive rocks in the Ningzhen area of east China: Partial melting of delaminated lower continental crust? Geology 2002, 30, 1111-1114. [CrossRef] 
80. Gao, S.; Rudnick, R.L.; Yuan, H.L.; Liu, X.M.; Liu, Y.S.; Xu, W.L.; Ling, W.L.; Ayers, J.C.; Wang, X.C.; Wang, Q.H. Recycling lower continental crust in the North China craton. Nature 2004, 432, 892-897. [CrossRef]

81. Moyen, J. High Sr/Y and La/Yb ratios: The meaning of the "adakitic signature". Lithos 2009, 112, 556-574. [CrossRef]

82. Rollinson, H.R. Using geochemical Data: Evaluation, Presentation, Interpretation; Longman Singapore Publishers (Pte) Ltd.: Singapore, 1993; pp. 1-352.

83. Fornelli, A.; Langone, A.; Micheletti, F.; Piccarreta, G. REE partition among zircon, orthopyroxene, amphibole and garnet in a high-grade metabasic system. Geol. Mag. 2018, 155, 1705-1726. [CrossRef]

84. Stern, C.R.; Kilian, R. Role of the subducted slab, mantle wedge and continental crust in the generation of adakites from the Andean Austral Volcanic Zone. Contrib. Miner. Petrol. 1996, 123, 263-281. [CrossRef]

85. Richards, J.P.; Spell, T.; Rameh, E.; Razique, A.; Fletcher, T. High Sr/Y magmas reflect arc maturity, high magmatic water content, and porphyry $\mathrm{Cu} \pm \mathrm{Mo} \pm \mathrm{Au}$ potential: Examples from the Tethyan arcs of Central and Eastern Iran and Western Pakistan. Econ. Geol. 2012, 107, 295-332. [CrossRef]

86. Xiong, X.L.; Adam, J.; Green, T.H. Rutile stability and rutile/melt HFSE partitioning during partial melting of hydrous basalt: Implications for TTG genesis. Chem. Geol. 2005, 218, 339-359. [CrossRef]

87. Wang, T.; Guo, L.; Zhang, L.; Yang, Q.D.; Zhang, J.J.; Tong, Y.; Ye, K. Timing and evolution of Jurassic-Cretaceous granitoid magmatisms in the Mongol-Okhotsk belt and adjacent areas, NE Asia: Implications for transition from contractional crustal thickening to extensional thinning and geodynamic settings. J. Asian Earth Sci. 2015, 97, 365-392. [CrossRef]

88. Wu, F.Y.; Lin, J.Q.; Wilde, S.A.; Zhang, X.O.; Yang, J.H. Nature and significance of the early cretaceous giant igneous event in Eastern China. Earth Planet. Sci. Lett. 2005, 233, 103-119. [CrossRef]

89. Yang, H.; Ge, W.; Yu, Q.; Ji, Z.; Liu, X.; Zhang, Y.; Tian, D. Zircon U-Pb-Hf isotopes, bulk-rock geochemistry and petrogenesis of middle to late Triassic I-type Granitoids in the Xing'an Block, Northeast China: Implications for early Mesozoic tectonic evolution of the Central Great Xing'an Range. J. Asian Earth Sci. 2016, 119, 30-48. [CrossRef]

90. Mao, A.Q.; Sun, D.Y.; Yang, D.G.; Tang, Z.Y.; Zheng, H. Petrogenesis and tectonic implications of Early Cretaceous volcanic rocks from the Shanghulin Basin within the northwestern Great Xing'an Range, NE China: Constraints from geochronology and geochemistry. Geol. J. 2018. [CrossRef]

91. Deng, C.Z.; Sun, D.Y.; Li, G.H.; Lu, S.; Tang, Z.Y.; Gou, J.; Yang, Y.J. Early Cretaceous volcanic rocks in the Great Xing'an Range: Late effect of a flat-slab subduction. J. Geodyn. 2019, 124, 38-51. [CrossRef]

92. Roberts, M.P.; Clemens, J.D. Origin of high-potassium, calc-alkaline, I-type granitoids. Geology 1993, 21, 825-828. [CrossRef]

93. Zorin, Y.A. Geodynamics of the western part of the Mongolia-Okhotsk collisional belt, Trans-Baikal region (Russia) and Mongolia. Tectonophysics 1999, 306, 33-56. [CrossRef]

94. Parfenov, L.M.; Popeko, L.I.; Tomurtogoo, O. Problems of tectonics of the Mongol-Okhotsk orogenic belt. Geol. Pac. Ocean 2001, 16, 797-830.

95. Mi, K.F.; Liu, Z.J.; Liu, R.B.; Li, C.F.; Wang, J.P.; Peng, R.M. U-Pb zircon, geochemical and Sr-Nd-Hf isotopic constraints on age and origin of the intrusions from Wunugetushan porphyry deposit, Northeast China: Implication for Triassic-Jurassic Cu-Mo mineralization in Mongolia-Erguna metallogenic belt. Int. Geol. Rev. 2018, 60, 496-512. [CrossRef]

96. Roelant, V.D.L.; Spikings, R.; Ulianov, A.; Chiaradia, M.; Mora, A. Paleozoic to early Jurassic history of the northwestern corner of Gondwana, and implications for the evolution of the Iapetus, Rheic and Pacific oceans. Gondwana Res. 2015, 31, 271-294.

97. Bustamante, C.; Cardona, A.; Archanjo, C.J.; Bayona, G.; Lara, M.; Valencia, V. Geochemistry and isotopic signatures of Paleogene plutonic and detrital rocks of the northern Andes of Colombia: A record of post-collisional arc magmatism. Lithos 2016, 277, 199-209. [CrossRef]

98. Cardona, A.; Valencia, V.; Garzón, A.; Montes, C.; Ojeda, G.; Ruiz, J.; Weber, M. Permian to Triassic I to S-type magmatic switch in the northeast Sierra Nevada de Santa Marta and adjacent regions, Colombian Caribbean: Tectonic setting and implications within Pangea paleogeography. J. S. Am. Earth Sci. 2010, 29, 772-783. [CrossRef]

99. Leal-Mejía, H.; Shaw, R.P.; Melgarejo, J.C. Phanerozoic granitoid magmatism in Colombia and the tectono-magmatic evolution of the Colombian Andes. In Geology and Tectonics of Northwestern South America; Cediel, F., Shaw, R.P., Eds.; Springer Nature: Basel, Switzerland, 2019. 
100. Pearce, J.A.; Harris, N.B.W.; Tindle, A.G. Trace element discrimination diagrams for the tectonic interpretation of granitic rocks. J. Petrol. 1984, 25, 956-983. [CrossRef]

101. Verma, S.P.; Pandarinath, K.; Verma, S.K.; Agrawal, S. Fifteen new discriminant-function-based multi-dimensional robust diagrams for acid rocks and their application to Precambrian rocks. Lithos 2013, 168-169, 113-123. [CrossRef]

102. Gorton, M.P.; Schandl, E.S. From continents to island arcs: A geochemical index of tectonic setting for arc-related and within-plate felsic to intermediate volcanic rocks. Can. Miner. 2000, 38, 1065-1073. [CrossRef]

103. Harris, R.A.; Stone, D.B.; Turner, D.L. Tectonic implications of Paleomagnetic and geochronologic data from the Yukon-Koyukuk province, Alaska. Geol. Soc. Am. Bull. 1987, 99, 362-375. [CrossRef]

104. Brown, M. Granite: From genesis to emplacement. Bull. Geol. Soc. Am. 2013, 125, 1079-1113. [CrossRef]

105. Reagan, M.K.; Hanan, B.B.; Heizler, M.T.; Hartman, B.S.; Hickey-Vargas, R. Petrogenesis of volcanic rocks from Saipan and Rota, Mariana islands, and implications for the evolution of nascent island arcs. J. Petrol. 2008, 49, 441-464. [CrossRef]

106. Tamura, Y.; Gill, J.B.; Tollstrup, D.; Kawabata, H.; Tatsumi, Y. Silicic magmas in the Izu-Bonin oceanic arc and implications for crustal evolution. J. Petrol. 2009, 50, 685-723. [CrossRef]

107. Barker, S.J.; Wilson, C.J.N.; Baker, J.A.; Millet, M.A.; Rotella, M.D.; Wright, I.C.; Wysoczanski, R.J. Geochemistry and petrogenesis of silicic magmas in the intra-oceanic Kermadec arc. J. Petrol. 2013, 54, 351-391. [CrossRef]

108. Lindsay, J.M.; Trumbull, R.B.; Siebel, W. Geochemistry and petrogenesis of late Pleistocene to recent volcanism in southern Dominica, lesser Antilles. J. Volcanol. Geotherm. Res. 2005, 148, 253-294. [CrossRef]

109. Leat, P.T.; Larter, R.D.; Millar, I.L. Silicic magmas of protector shoal, south Sandwich arc: Indicators of generation of primitive continental crust in an island arc. Geol. Mag. 2007, 144, 179. [CrossRef]

110. Turner, S.; Caulfield, J.; Rushmer, T.; Turner, M.; Cronin, S.; Smith, I.; Handley, H. Magma evolution in the primitive, intra-oceanic Tonga arc: Rapid petrogenesis of dacites at Fonualei volcano. J. Petrol. 2012, 53, 1231-1253. [CrossRef]

111. Meng, E.; Xu, W.L.; Yang, D.B.; Qiu, K.F.; Li, C.H.; Zhu, H.T. Zircon U-Pb chronology, geochemistry of Mesozoic volcanic rocks from the Lingquan basin in Manzhouli area, and its tectonic implications. Acta Petrol. Sin. 2011, 27, 1209-1226. (In Chinese with English Abstract).

112. Donskaya, T.V.; Gladkochub, D.P.; Mazukabzov, A.M.; Ivanov, A.V. Late Paleozoic-Mesozoic subduction-related magmatism at the southern margin of the Siberian continent and the 150 million-year history of the Mongol-Okhotsk Ocean. J. Asian Earth Sci. 2013, 62, 79-97. [CrossRef]

113. Bussien, D.; Gombojav, N.; Winkler, W.; von Quadt, A. The Mongol-Okhotsk Belt in Mongolia-An appraisal of the geodynamic development by the study of sandstone provenance and detrital zircons. Tectonophysics 2011, 510, 132-150. [CrossRef]

114. Rapp, R.P.; Shimizu, N.; Norman, M.D.; Applegate, G.S. Reaction between slab-derived melts and peridotite in the mantle wedge: Experimental constraints at 3.8 GPa. Chem. Geol. 1999, 160, 335-356. [CrossRef]

115. Axen, G.J.; van Wijk, J.W.; Currie, C.A. Basal continental mantle lithosphere displaced by flat-slab subduction. Nat. Geosci. 2018, 11, 961-964. [CrossRef]

116. Gutscher, M.A. Scraped by fat-slab subduction. Nat. Geosci. 2018, 11, 889-893. [CrossRef]

117. Stern, C.R. Subduction erosion: Rates, mechanisms, and its role in arc magmatism and the evolution of the continental crust and mantle. Gondwana Res. 2011, 20, 284-308. [CrossRef]

118. Sun, W.D.; Ling, M.X.; Yang, X.Y.; Fan, W.M.; Ding, X.; Liang, H.Y. Ridge subduction and porphyry copper-gold mineralization: An overview. Sci. China Earth Sci. 2010, 53, 475-848. [CrossRef]

119. Thorkelson, D.J.; Madsen, J.K.; Sluggett, C.L. Mantle flow through the Northern Cordilleran slab window revealed by volcanic geochemistry. Geology 2011, 39, 267-270. [CrossRef]

120. Ranero, C.R.; von Huene, R. Subduction erosion along the Middle America convergent margin. Nature 2000, 404, 748-752. [CrossRef]

(C) 2020 by the authors. Licensee MDPI, Basel, Switzerland. This article is an open access article distributed under the terms and conditions of the Creative Commons Attribution (CC BY) license (http://creativecommons.org/licenses/by/4.0/). 